\title{
Internal ornamentation of the first proctodeal segment of the digestive tube of Syntermitinae (Isoptera, Termitidae)
}

\author{
Mauricio M. Rocha ${ }^{1}$, Joice P. Constantini ${ }^{1}$ \\ 1 Museu de Zoologia da Universidade de São Paulo, Cx. Postal 42.494, 04218-970 São Paulo, SP, Brazil \\ http://zoobank.org/9861480D-4CBF-4B33-B08A-80F10E3C9D6F \\ Corresponding author: Mauricio M. Rocha (mrocha@usp.br)
}

Received 4 September 2014

Accepted 20 February 2015

Published 4 March 2015

Academic editor:

Susanne Randolf

\section{Key Words}

Mandibulate nasute termites

gut anatomy

feeding habits

microbial inoculation

\begin{abstract}
The ornaments inside the first proctodeal segment of the digestive tube in thirty-three species of the termite subfamily Syntermitinae are described and illustrated, encompassing all genera of the subfamily. The occurrence, type and pattern of the ornamentation reveal a wide morphological diversity. A first proposal for classification and nomenclature of these structures and coverage patterns is included, as well as a discussion of possible functions.
\end{abstract}

\section{Introduction}

The termite gut is specialized for the digestion of lignocellulosic resources. Unlike other insects, the hindgut is compartmentalized, and five segments can be recognized: ileum, or first proctodeal segment (P1); enteric valve, or second proctodeal segment (P2); paunch, or third proctodeal segment $(\mathrm{P} 3)$; colon, or fourth proctodeal segment (P4); and rectum, or fifth proctodeal segment (P5) (Noirot 1995). During the evolution of termites, many groups evolved more anatomically and physiologically complex adaptations that allowed them to diversify their diet. For example, members of the subfamily Cubitermitinae, a well-characterized soil-feeder group, have a specialized diverticulum connected to the P3, and a complex physiology that regulates the $\mathrm{pH}$ and the oxygen supply in the gut compartments (Brune 2014). The digestive process, mediated by symbionts, occurs mainly in the P3, but the entire gut is important for digestion.

The gut characters are important for termite taxonomy. One of the first comprehensive studies employing gut anatomy was that of Sands (1972), who reorganized a complex of soldierless termite species and described 16 new genera, based mainly on these characters; additionally, Sands revamped the entire classification of Termitidae. Although Sands never employed the P1 ornaments, his work is a good example of how the morphology of the gut can be taxonomically informative for Isoptera. Although the internal ornaments have been widely used in termite systematics, the major focus has been on P2, and published information about other segments is sparse.

Kovoor (1969) contributed the first comparative study of the anatomy of the digestive tube of termites, including species of Syntermitinae (at that time considered as part of Nasutitermitinae). She described the gut of Cornitermes cumulans, Labiotermes pelliceus, Procornitermes triacifer, Rhynchotermes nasutissimus, Syntermes dirus and an unspecified species of "Armitermes" (probably Silvestritermes euamignathus), emphasizing important morphological differences between the "mandibulate nasutes" and "true nasutes", which today are assigned to the Syntermitinae and Nasutitermitinae, respectively. Kovoor (1969) mentioned the existence of ornamentation inside the (P1) in Syntermitinae, describing and 
illustrating this ornamentation for Syntermes dirus (only by a small indication, without details) and describing a slightly different arrangement of spines for other species of the Syntermes-group. However, she did not discuss the possible significance of the differences or make a detailed microscopic examination of the ornamentation.

The papers of Noirot $(1995,2001)$ systematized the knowledge of termite gut anatomy, establishing a nomenclature and comparing a wide range of species from all families and subfamilies of Isoptera, and also the wood roach Cryptocercus, the sister-group of termites (Krishna et al. 2013). Noirot (1995) described the first proctodeal segment in lower termites. In these groups the P1 is very short and has six internal cushions, with tri-radial symmetry and ornamented with small spines, similar to Cryptocercus. Noirot (2001) indicated that the ornamentation, although reduced, persists in the subfamily Macrotermitinae, but for the other groups of Termitidae it is not clear if there is a pattern.

Except for the study of Kovoor (1969), the P1 internal ornaments are neglected in termite literature, particularly for species of Termitidae. Even in the most comprehensive termite treatises that include information about the gut anatomy (Grassé 1982; Krishna et al. 2013; Noirot 1995, 2001), the existence of these ornaments is only mentioned, and there is no specific description, categorization or hypothesis respecting their function. As mentioned above, Noirot $(1995,2001)$ described a generalized pattern for the families of lower termites, but except for few notes about Macrotermitinae, almost nothing is mentioned for Termitidae, which comprise two-thirds of Isoptera species. Besides, Termitidae have a much larger food repertoire compared with the lower termites, that feed strictly wood (Brune 2014).

Herein we describe and compare the internal ornamentation of the first proctodeal segment for a comprehensive set of Syntermitinae species, and propose, for the first time, a comparative nomenclature for these structures and coverage patterns. There is wide variation within the subfamily, and insights about the taxonomic value, classification by feeding habits, and function in termite digestion are discussed.

\section{Materials and methods}

The specimens studied are deposited in the Museu de Zoologia da Universidade de São Paulo (MZUSP), São Paulo, Brazil. We dissected individuals of 36 species of Syntermitinae, covering all genera (Table 1). These represented nearly one-third of the 101 described taxa of Syntermitinae, and were chosen by a previous examination of all subfamily species to include the most representative.

The arrangement of the ornamentation is represented by schematic drawings. Since in the Syntermitinae the P1 is inflated and globose, it is impossible to photograph or illustrate the complete coverage exactly as it exists in situ and on the actual scale. The plan of the dissections is explained in Fig. 1.
Table 1. Genera and species studied.

\begin{tabular}{|c|c|}
\hline Genera (total number of described species) & Studied species \\
\hline Acangaobitermes (1) & A. krishnai \\
\hline \multirow{3}{*}{ Armitermes (3) } & A. armiger \\
\hline & A. bidentatus \\
\hline & A. spininotus \\
\hline Cahuallitermes (2) & C. intermedius \\
\hline \multirow{4}{*}{ Cornitermes (14) } & C. acignathus \\
\hline & C. cumulans \\
\hline & C. bolivianus \\
\hline & C. silvestrii \\
\hline Curvitermes (2) & C. odontognathus \\
\hline Cyrilliotermes (4) & C. angulariceps \\
\hline \multirow{6}{*}{ Embiratermes (14) } & E. brevinasus \\
\hline & E. festivellus \\
\hline & E. heterotypus \\
\hline & E. ignotus \\
\hline & E. robustus \\
\hline & E. silvestrii \\
\hline \multirow{2}{*}{ Ibitermes (3) } & I. curupira \\
\hline & I. tellustris \\
\hline \multirow{4}{*}{ Labiotermes (10) } & L. emersoni \\
\hline & L. labralis \\
\hline & L. leptothrix \\
\hline & L. orthocephalus \\
\hline Macuxitermes (1) & M. triceratops \\
\hline Mapinguaritermes (2) & M. peruanus \\
\hline Noirotitermes (1) & N. noiroti \\
\hline Paracurvitermes (1) & P. manni \\
\hline \multirow{3}{*}{ Procornitermes (5) } & P. araujoi \\
\hline & P. lespesii \\
\hline & P. triacifer \\
\hline \multirow{2}{*}{ Rhynchotermes (7) } & R. nasutissimus \\
\hline & $R$. perarmatus \\
\hline Silvestritermes (7) & S. euamignathus \\
\hline \multirow{2}{*}{ Syntermes (23) } & S. molestus \\
\hline & S. spinosus \\
\hline Uncitermes (1) & U. teevani \\
\hline
\end{tabular}

The structures were removed, mounted in glycerin, and photographed under an optical microscope (Zeiss Microscope Axionskop 2 coupled to a computer). The terminology adopted for the digestive tube follows Noirot (2001).

\section{Results}

The analysis of the P1 ornamentation revealed a wide diversity of structures and patterns (Figs 2-25). The structures can be categorized by form and relative arrangement, and the ornamentation by the types of spines and their abundance. As a specific nomenclature for these structures does not exist, we propose some terms that are discussed below.

\section{Categories of structures}

Aciculiform spines are slender and straight. They vary in size from relatively large (around $20 \mu \mathrm{m}$; for example, Figs $5 \mathrm{~b}, 10 \mathrm{~b}, 18 \mathrm{c}, 22 \mathrm{~b}, 22 \mathrm{c}$ ) to relatively small (around 5 

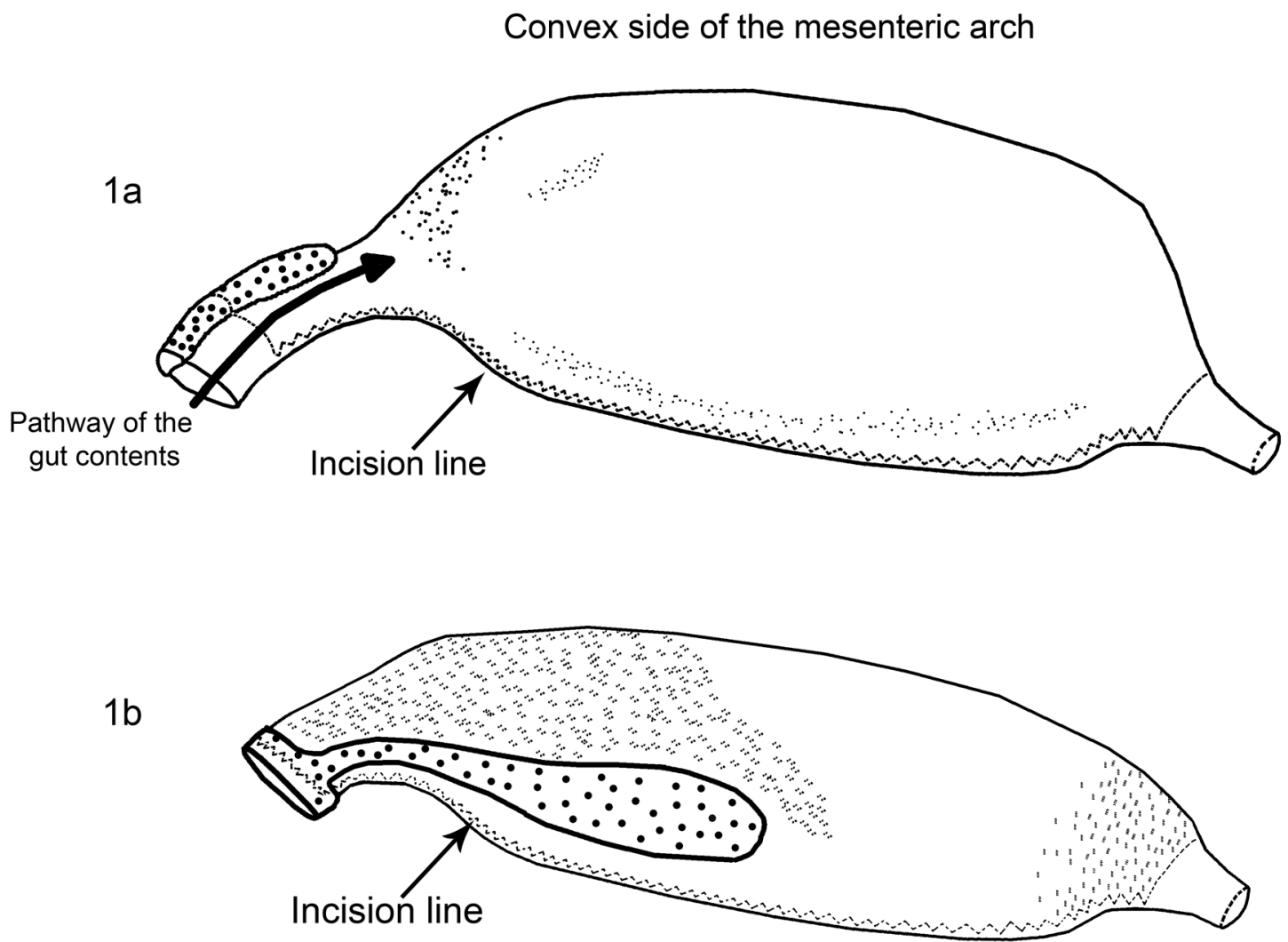

Figure 1. First proctodeal segment (P1), diagrammatic illustrations showing the line of incision most often used in this study. (a) Silvestritermes euamignathus, mesenteric tongue and ornamentation situated on convex side of mesenteric arch; (b) Rhynchotermes nasutissimus, ornamentation situated on convex side of mesenteric arch and mesenteric tongue twisted.
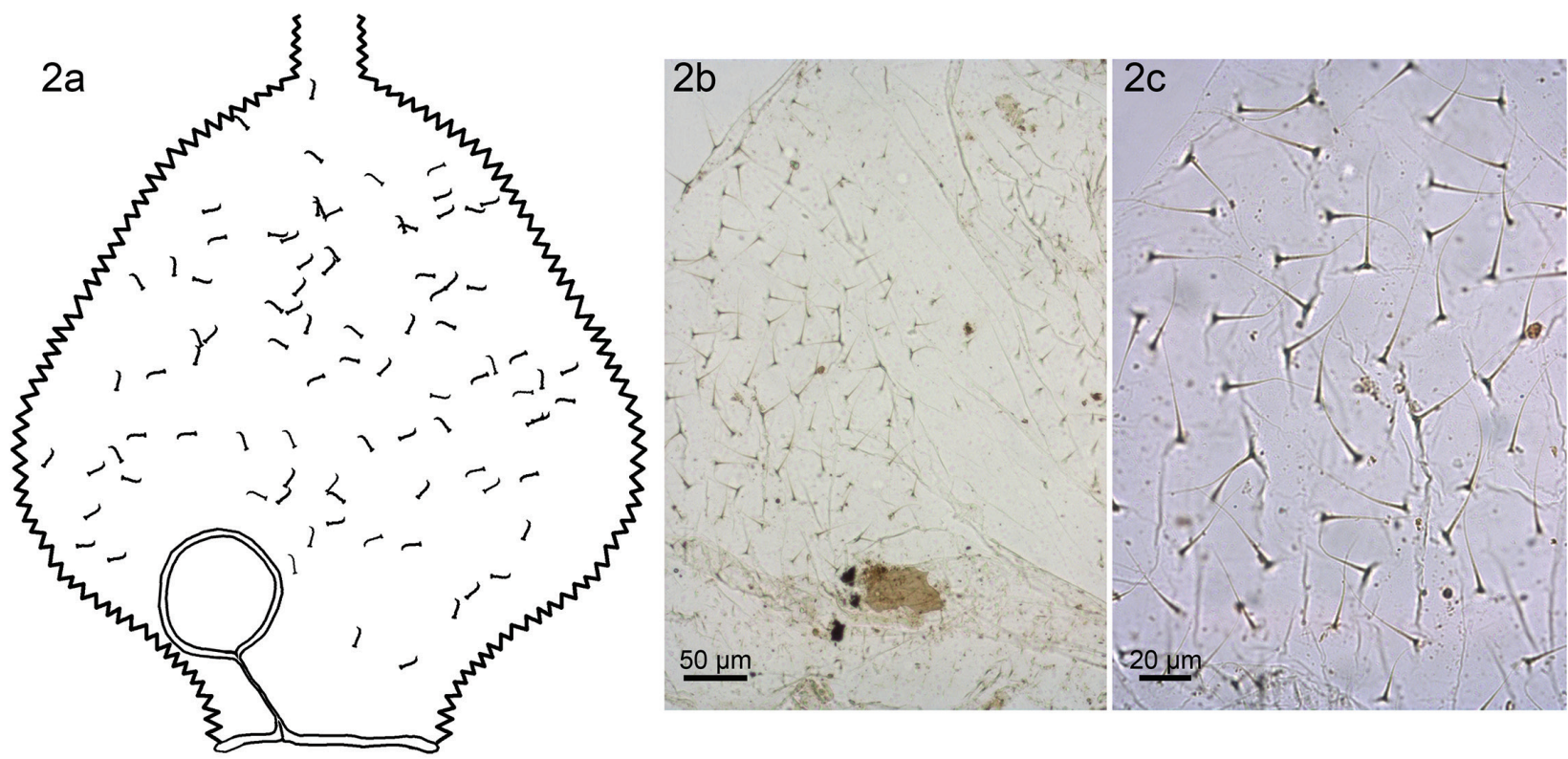

Figure 2. Armitermes spininotus. (a) Schematic drawing of P1 showing arrangement of ornamentation. (b, c) Photomicrographs: (b) General view; (c) Detail of ornamentation of thin setae.

$\mu \mathrm{m}$, Figs $6 \mathrm{~b}, 6 \mathrm{c})$, and in some species these spines have a sclerotized base (Figs 3b, 21b, 23d, 23e, 24c). Two variations of the aciculiform type are the trifurcated spines (Fig. 8b) and thin setae (Fig. 2c).
Robust spines are relatively short (around $10 \mu \mathrm{m}$ ), with a simple conical shape. They are sparsely distributed (Figs 16b, 25b). 

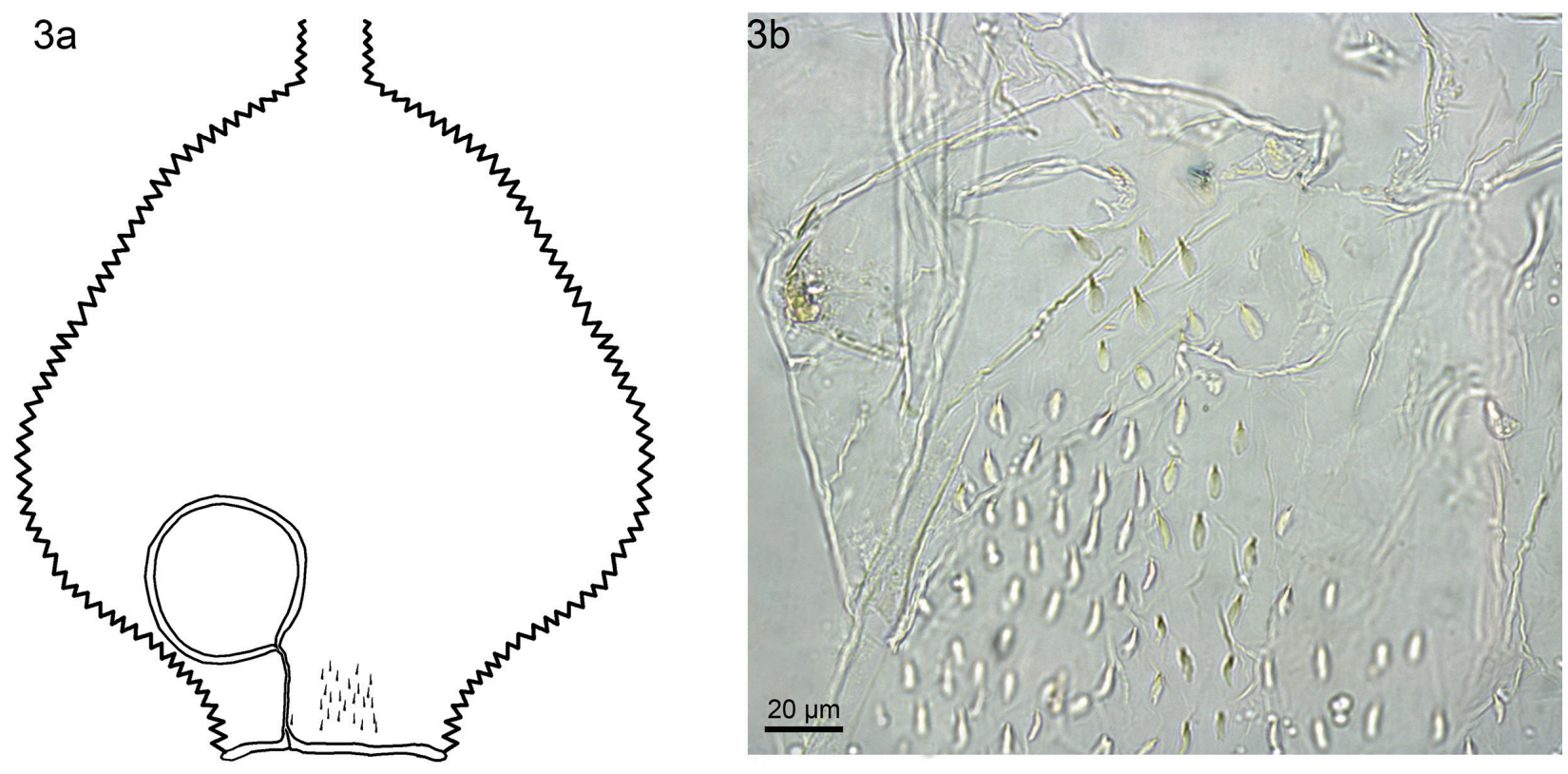

Figure 3. Cornitermes bolivianus. (a) Schematic drawing of P1 showing arrangement of spines; (b) Photomicrograph showing detail of spines with sclerotized bases.
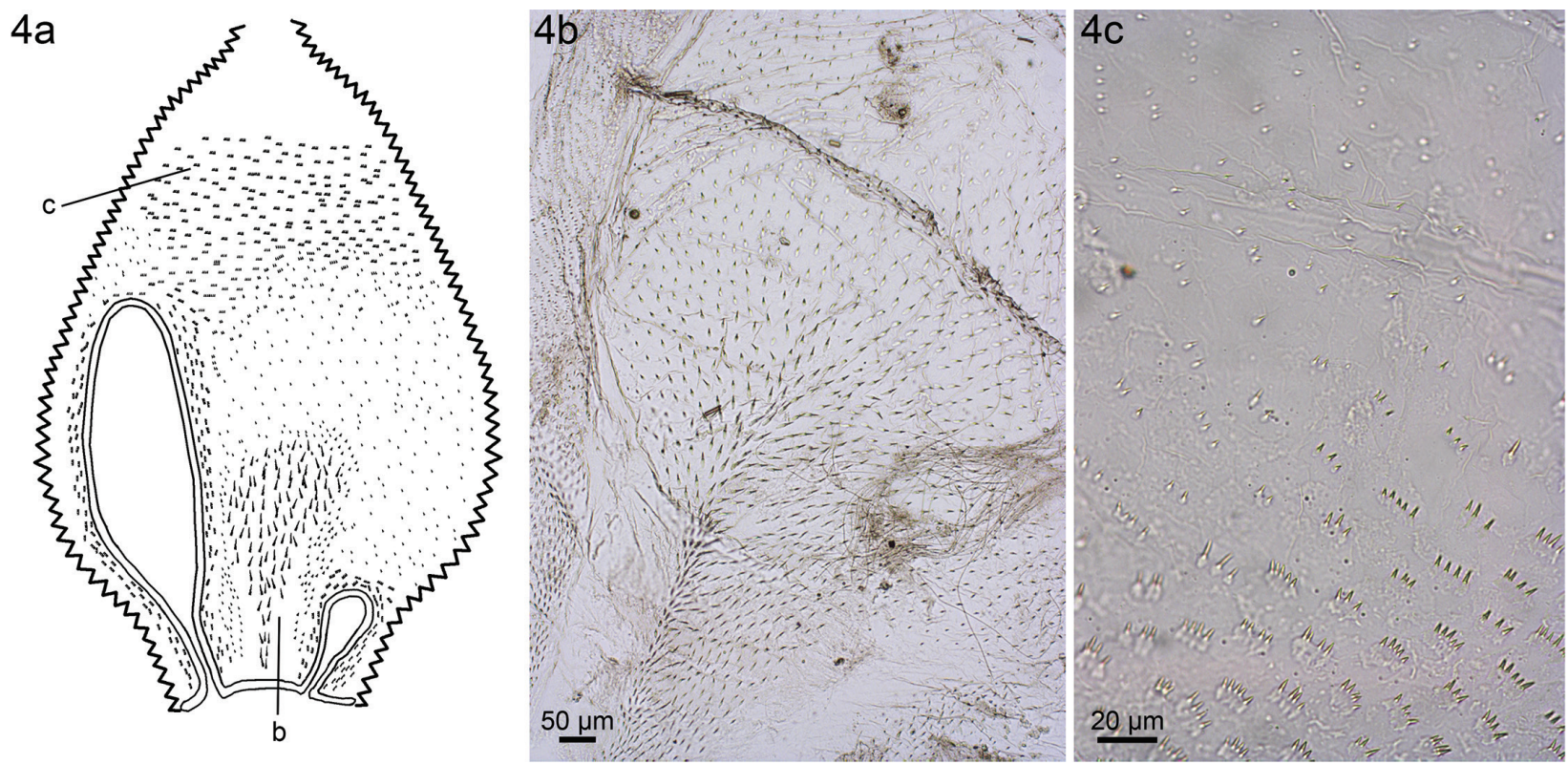

Figure 4. Cornitermes cumulans. (a) Schematic drawing of P1 showing arrangement of spines. (b, c) Photomicrographs: (b) Aciculiform spines, situated between the mesenteric tongues; (c) Detail of short spines in rows, present around the mesenteric tongues and next to $\mathrm{P} 2$.

Stout spines are similar to robust spines, but larger and sometimes slightly curved; they may be arranged longitudinally (Figs $11 \mathrm{c}, 16 \mathrm{c}$ ) or regularly alternating (Fig. 12d).

The central ridges, present in some species of $\mathrm{La}$ biotermes (Figs 13c, 14c, 15c), are single structures, composed of spines with their bases fused, arranged in a helical pattern. These ridges are probably homologous to the longitudinal arrangement of stout spines in Ibitermes curupira and Mapinguaritermes (Figs 11c, 16c), since their placements are equivalent inside P1.
Small spines in rows (Figs 4c, 21c, 23c, 23f) are tiny and have a typical transverse arrangement in units of 2-6 spines.

\section{Patterns of ornamentation}

The coverage and abundance of spines can be categorized in four types of patterns.

Proximal aciculiform pattern: composed by aciculiform spines, restricted to the proximal region (Figs $5 \mathrm{a}$, 6a, 9a, 10a, 17a, 18a, 20a, 22c), and usually with three groups of small spines in the distal portion (Figs 6c, 9c, 

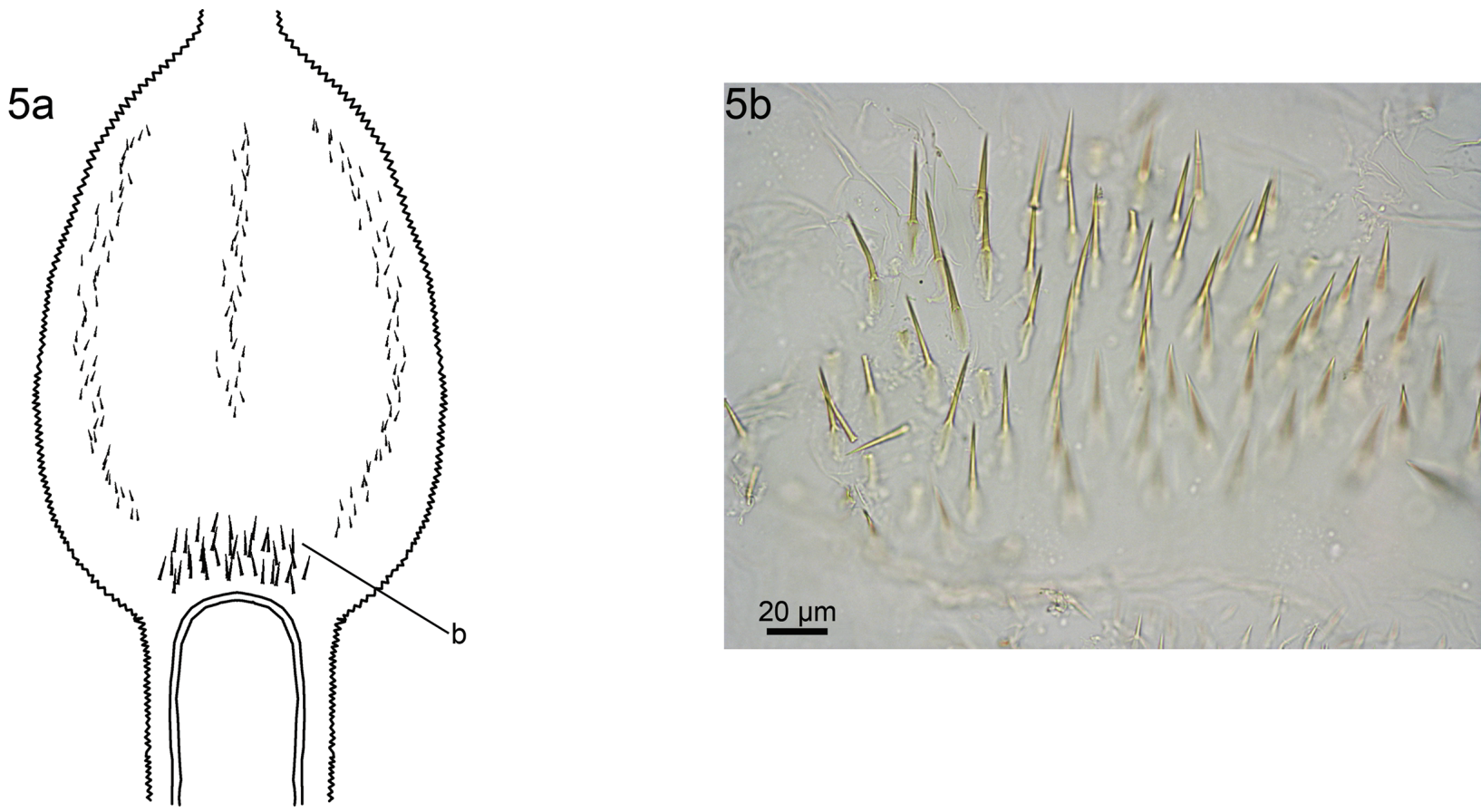

Figure 5. Curvitermes odontognathus. (a) Schematic drawing of P1 showing arrangement of spines; (b) Photomicrograph of set of aciculiform spines, positioned just after the mesenteric tongue.

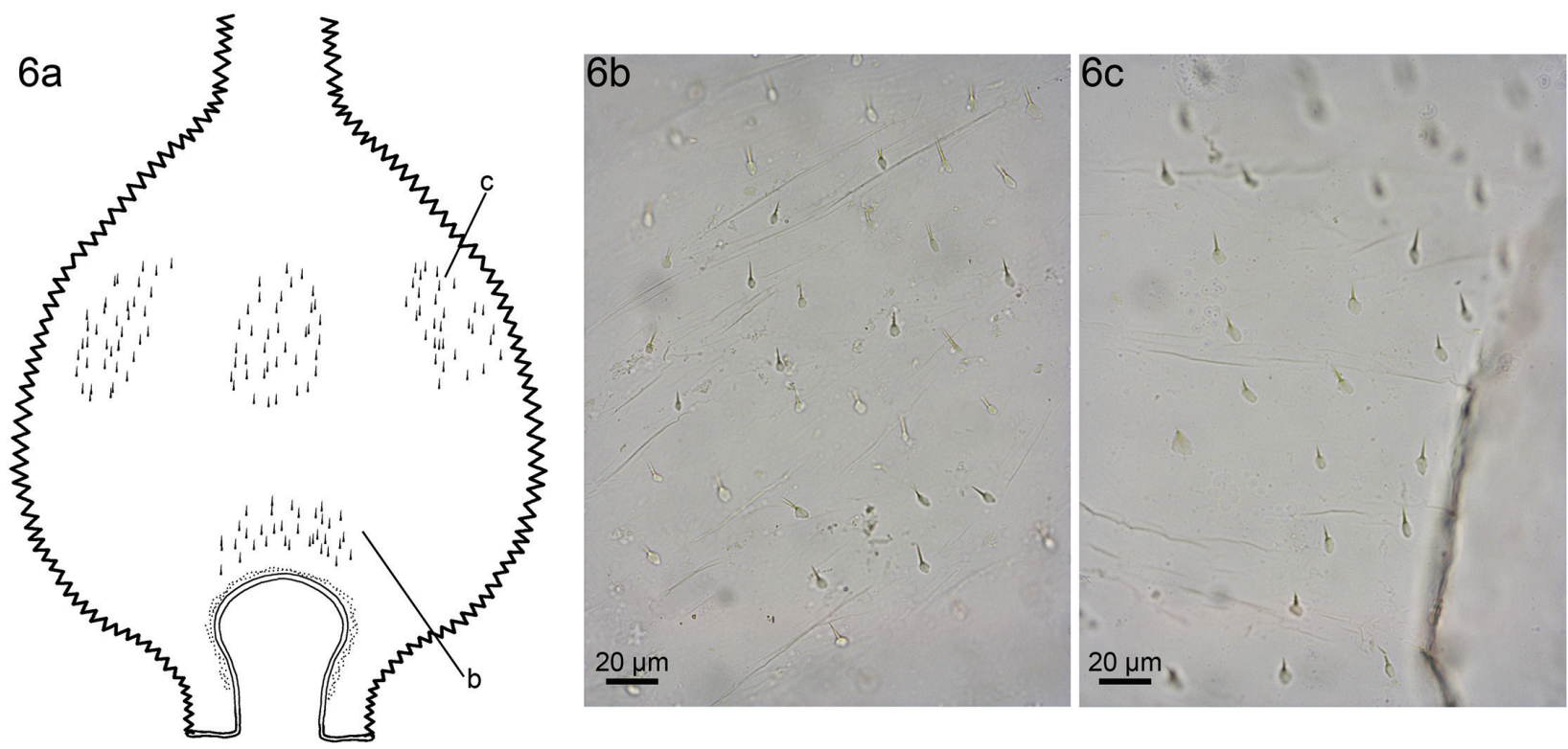

Figure 6. Cyrilliotermes angulariceps. (a) Schematic drawing of $\mathrm{P} 1$ showing arrangement of spines. (b, c) Photomicrographs: (b) Reduced spines located in proximal region. (c) Spines in distal region.

$18 \mathrm{~b}, 20 \mathrm{~b})$, the following species can be included in this category:

Acangaobitermes krishnai: Identical to N. noiroti (see ahead).

Curvitermes odontognathus (Fig. 5): A group of aciculiform spines is located just after the mesenteric tongue (Fig. 5b), at the distal region three long branches of small spines are present.
Cyrilliotermes angulariceps (Fig. 6): The coverage is composed only by small aciculiform spines, one group located just after the mesenteric tongue (Fig. 6b), and three ovate areas are present at the distal region (Fig. $6 c)$.

Embiratermes brevinasus: identical to E. ignotus (see ahead).

Embiratermes festivellus (Fig. 10): A triangular area of aciculiform spines is located just after the mesenteric 


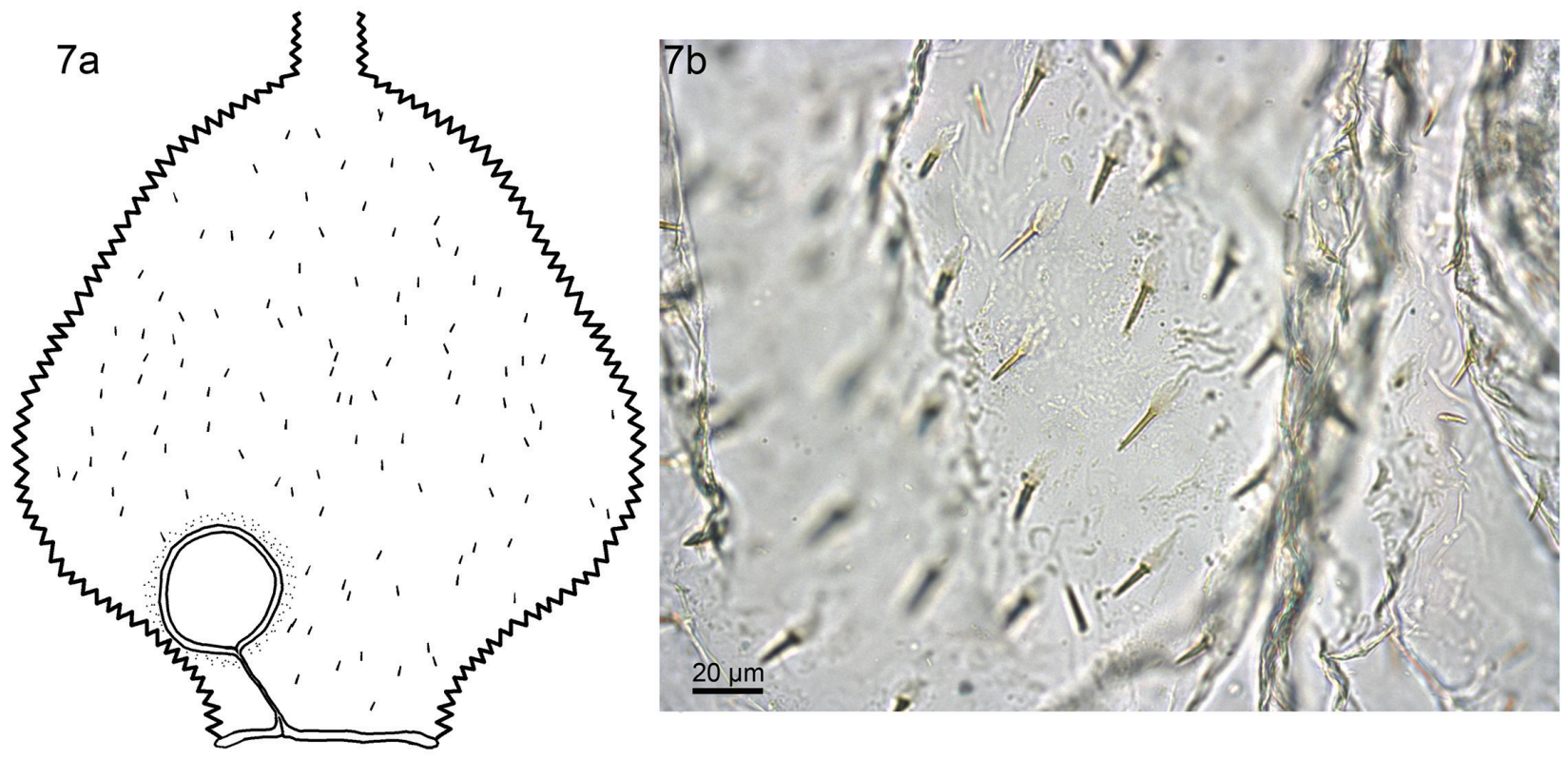

Figure 7. Embiratermes heterotypus. (a) Schematic drawing of P1 showing arrangement of spines; (b) Photomicrograph showing detail of aciculiform spines.
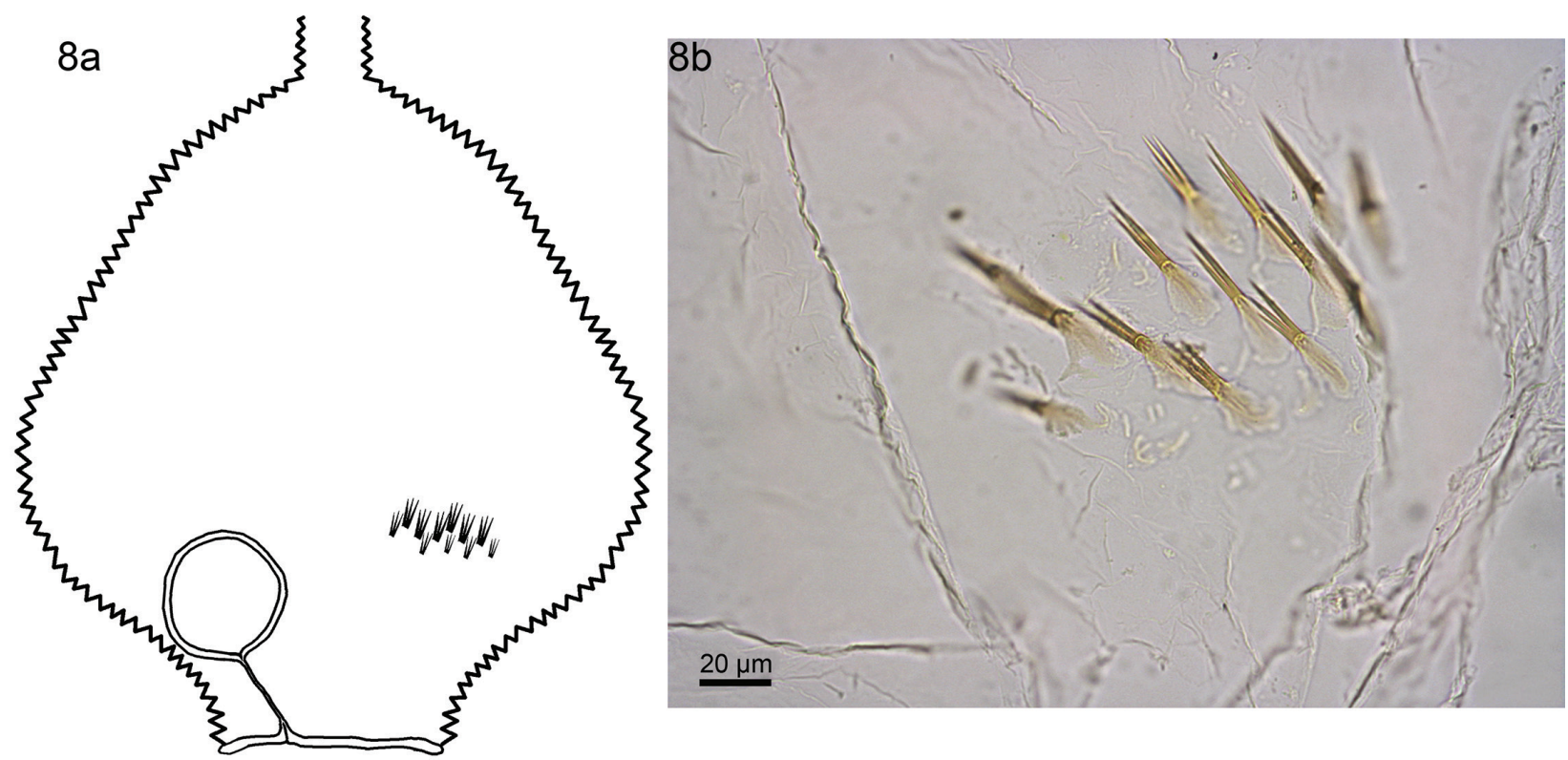

Figure 8. Embiratermes ignotus. (a) Schematic drawing of P1 showing arrangement of spines; (b) Photomicrograph showing detail of trifurcated spines.

tongue (Fig. 10b), and three oval areas, covered with small aciculiform spines, present at the distal region.

Embiratermes ignotus (Fig. 8): The only ornament is a single transversal row of trifurcate spines, placed laterally to the mesenteric tongue (Fig. 8b).

Embiratermes silvestrii (Fig. 9): An oval area of aciculiform spines is located laterally to the mesenteric tongue (Fig. 9b), and three branches of small spines, one long and two shorts, are present at the distal region (Fig. 9c).

Ibitermes tellustris: very similar to E. silvestrii (see above).
Macuxitermes triceratops: (Fig. 17): An elongated area of aciculiform spines is placed close and laterally to the mesenteric tongue (Fig. 17c), the distal portion is broadly covered by sparse small spines (Fig. 17b).

Noirotitermes noiroti (Fig. 18): A group of aciculiform spines is located laterally to the mesenteric tongue (Fig. 18c), and at the distal region three long branches of small spines are present (Fig. 18b).

Paracurvitermes manni (Fig. 20): A transversal row of aciculiform spines, placed laterally to the mesenteric tongue is located laterally to the mesenteric tongue 


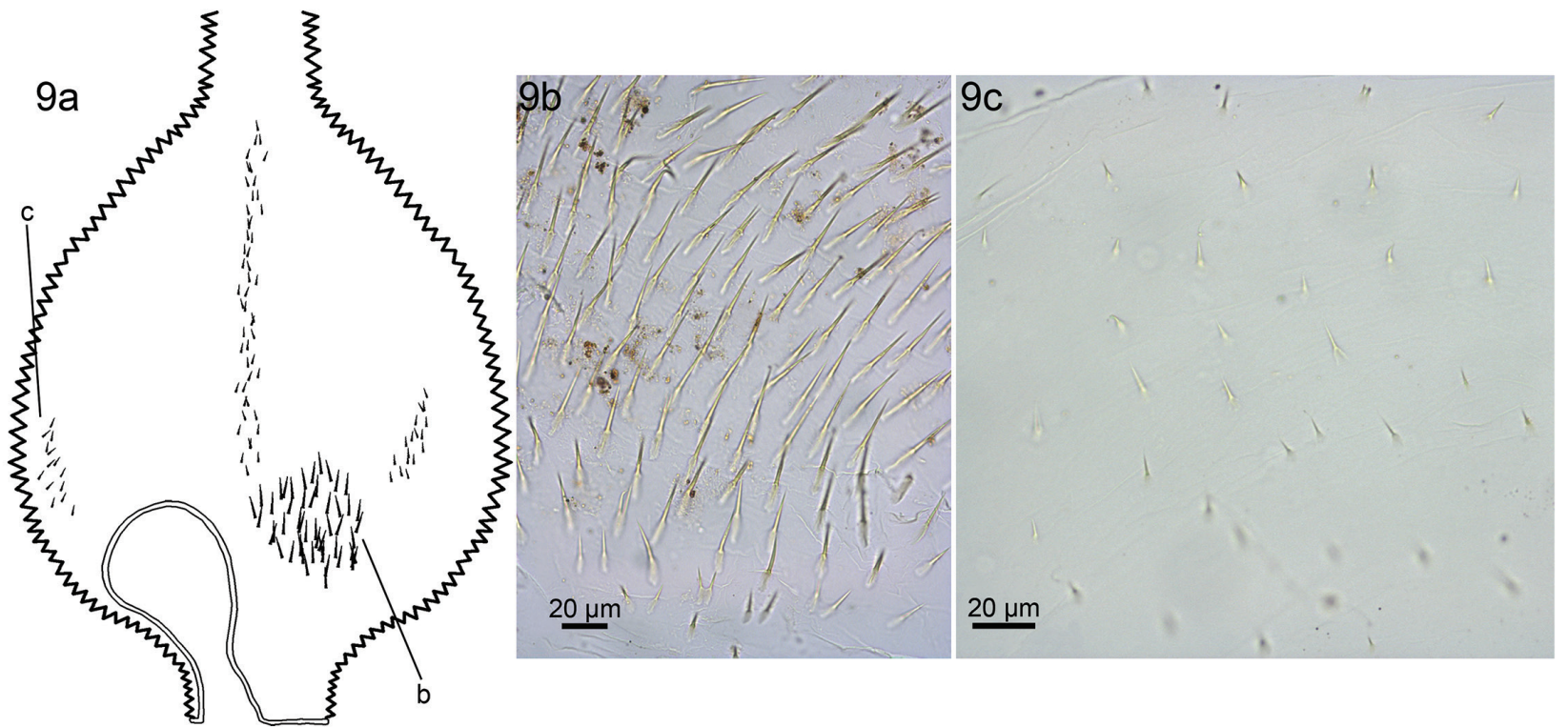

Figure 9. Embiratermes silvestrii. (a) Schematic drawing of P1 showing arrangement of spines. (b, c) Photomicrographs: (b) Set of aciculiform spines in detail; (c) Spines of the distal branches in detail.
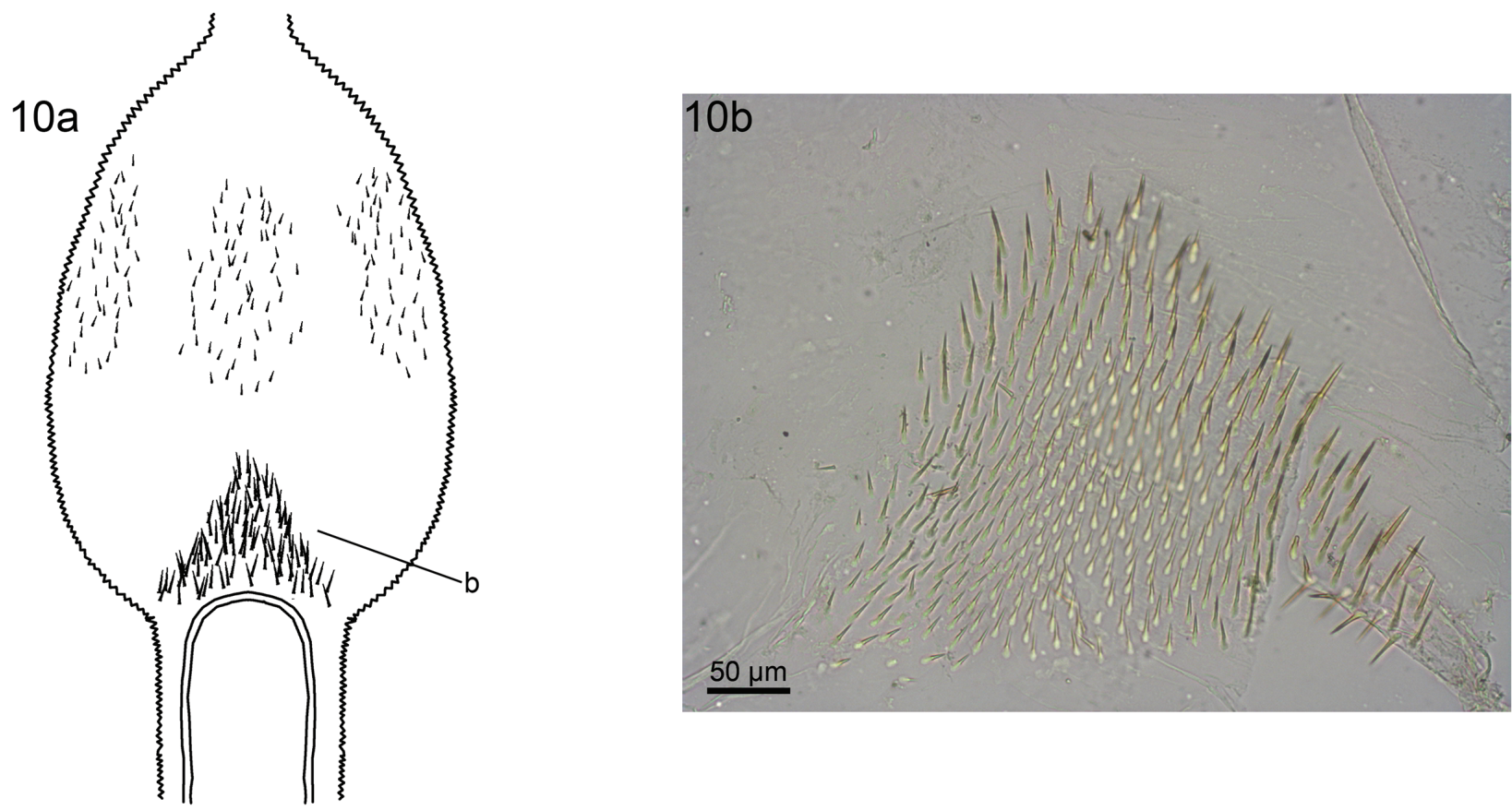

Figure 10. Embiratermes festivellus. (a) Schematic drawing of P1 showing arrangement of spines; (b) Photomicrograph showing detail of aciculiform spines.

(Fig. 20c), and three branches of small spines, one long and two shorts, are present at the distal region (Fig. 20b).

Silvestritermes euamignathus (Fig. 22): A triangular area of aciculiform spines is located just after the mesenteric tongue (Fig. 22c), the aciculiform spines form a singular palisade around the mesenteric tongue (Fig. 22b). Three branches of small spines, one long and two very short, are present at the distal region.
Central ridge pattern: characterized by the presence of a longitudinal row of stout spines (Figs 11a, 16a) or the central ridge (Figs 12a, 13a, 14a, 15a), commonly surrounded by robust spines, the following species can be included in this category:

Embiratermes robustus: very similar to M. peruanus (see ahead).

Ibitermes curupira (Fig. 11): The ornaments are concentrated laterally to the mesenteric tongue, a longitudinal 

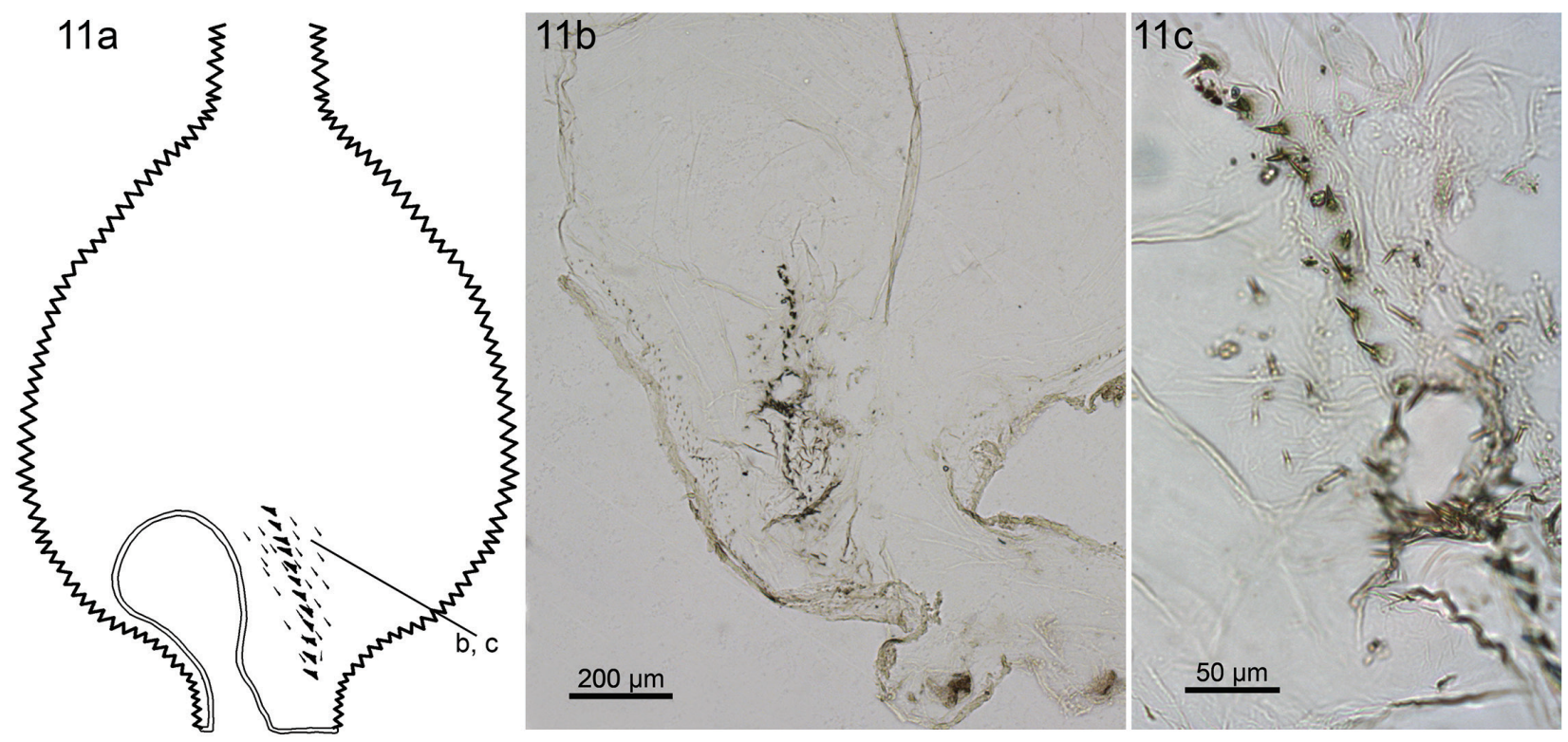

Figure 11. Ibitermes curupira. (a) Schematic drawing of P1 showing arrangement of spines. (b, c) Photomicrographs: (b) General view of longitudinal row of stout spines, with some robust spines nearby (middle of P1 wall slightly damaged); (c) Detail of stout spines.
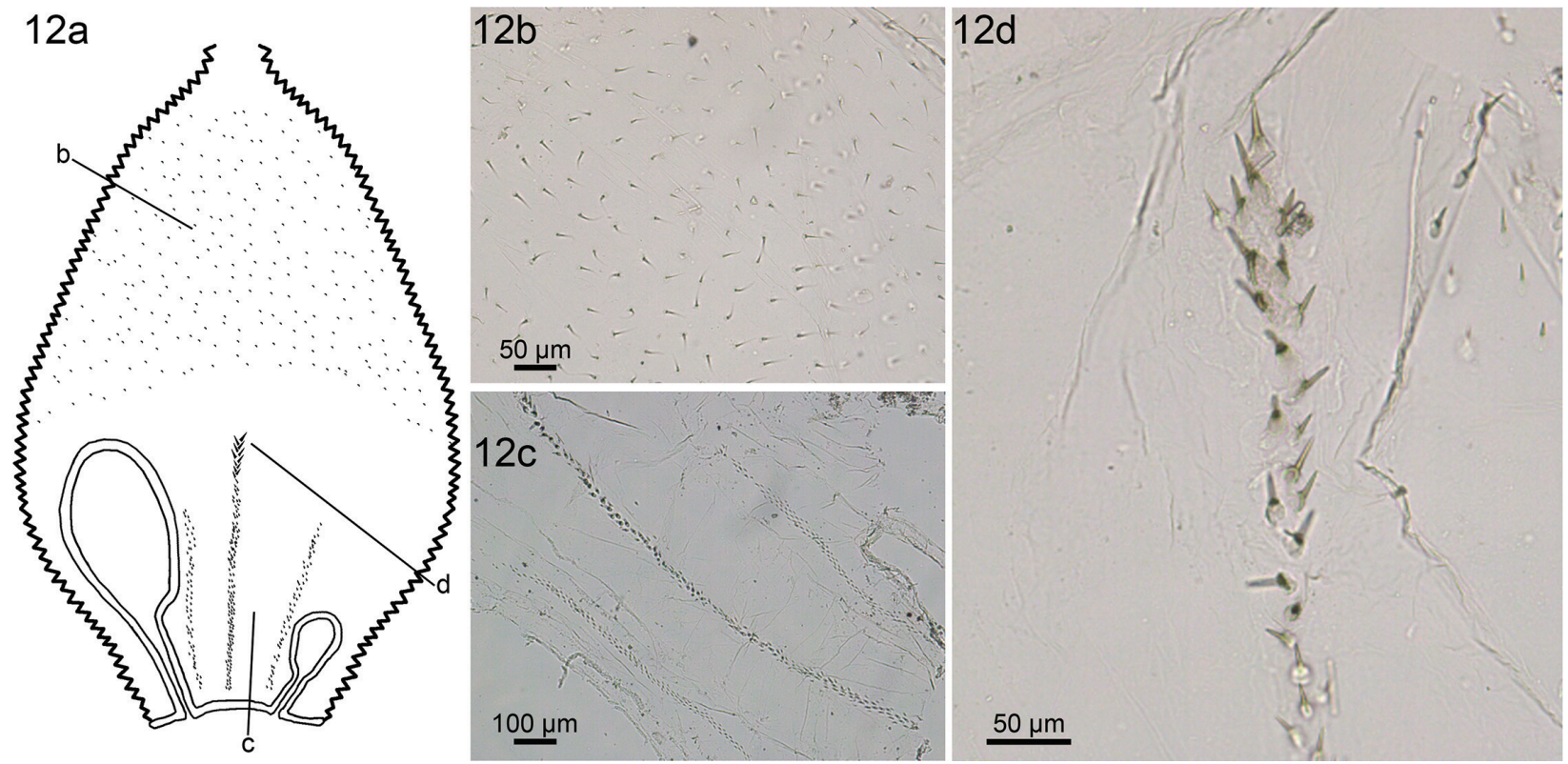

Figure 12. Labiotermes emersoni. (a) Schematic drawing of $\mathrm{P} 1$ showing arrangement of spines. (b-d) Photomicrographs: (b) Detail of spines in the distal region; (c) General view of the three branches of spines between the mesenteric tongues; (d) Detail of middle branch of spines.

row of 20-25 stout spines (Fig. 11c), and few robust spines spaced distributed around the stout spines.

Labiotermes emersoni (Fig. 12): At the proximal region, between the mesenteric tongues, three longitudinal rows of robust spines (Fig. 12c) with the central ridge at the apex of the middle row (Fig. 12d), distal region covered with spaced small bristles (Fig. 12b).

Labiotermes labralis (Fig. 13): The internal surface is all covered with spaced robust spines (Fig. 13b), with a small central ridge (Fig. 13a).
Labiotermes leptothrix (Fig. 14): The central ridge is " $\mathrm{S}$ " shaped, well sclerotized with the fused spines (Fig. 14a), distal region covered with spaced robust spines.

Labiotermes orthocephalus (Fig. 15): The central ridge is composed by 10-15 slightly fused spines (Fig. 15c); distal region is covered with spaced robust spines (Fig. 15b).

Mapinguaritermes peruanus (Fig. 16): The ornaments are concentrated laterally to the mesenteric tongue, a longitudinal row of 15-20 stout spines (Fig. 16c), and robust spines spaced distributed around. 

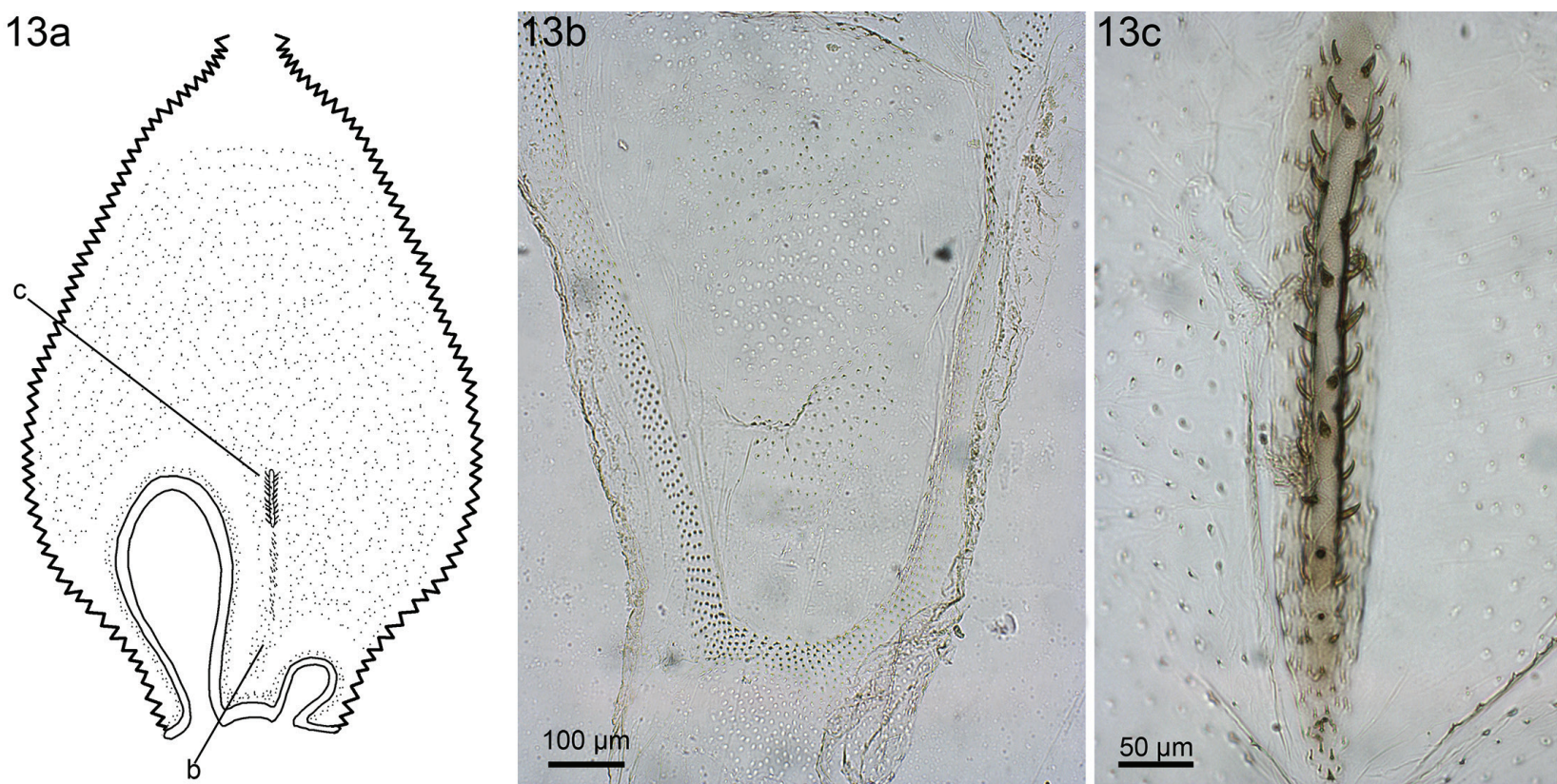

Figure 13. Labiotermes labralis. (a) Schematic drawing of P1 showing arrangement of spines. (b, c) Photomicrographs: (b) Detail of the coverage of small robust spines between the mesenteric tongues; (c) Detail of central ridge structure.
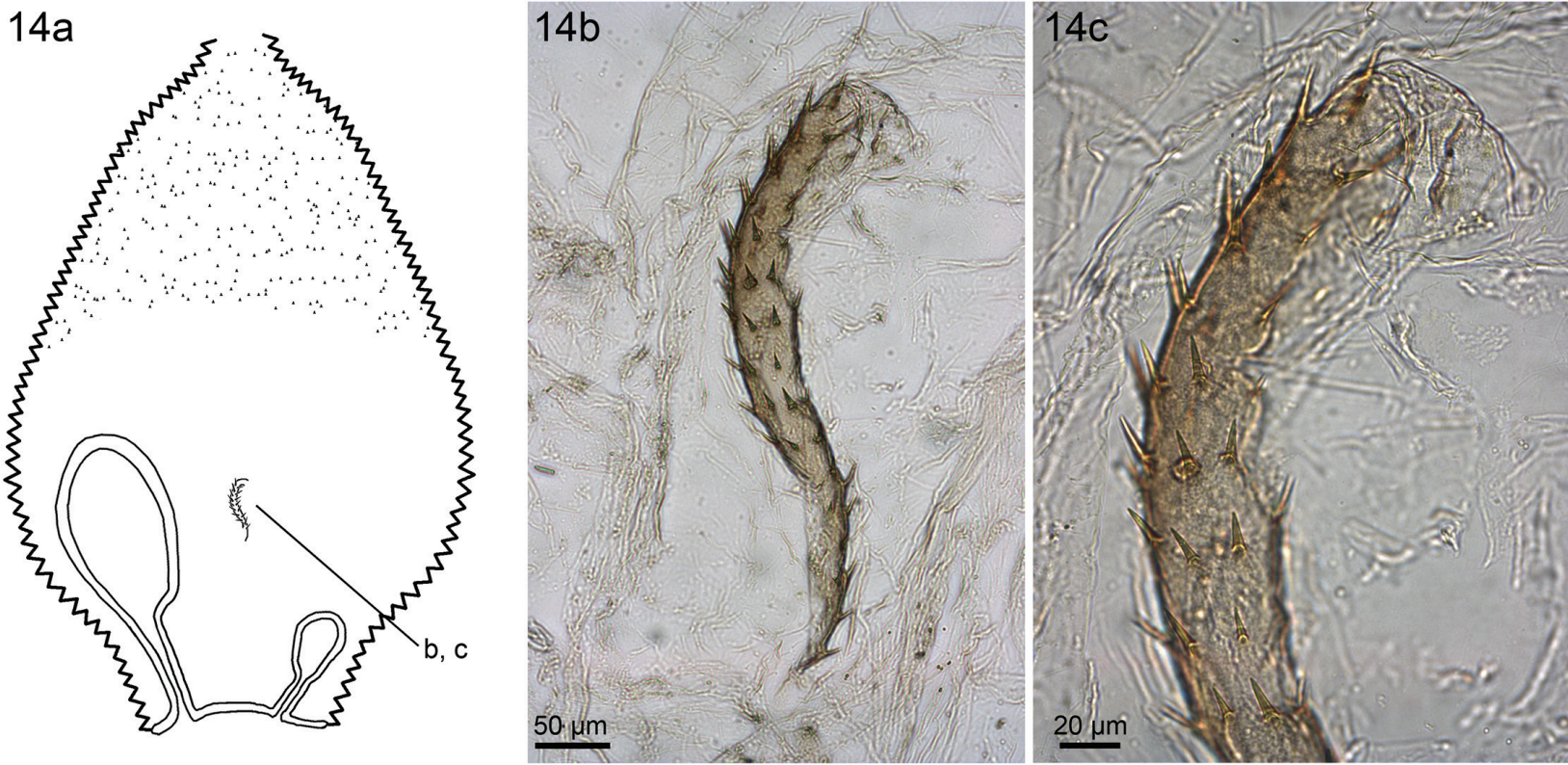

Figure 14. Labiotermes leptothrix. (a) Schematic drawing of P1 showing arrangement of spines. (b, c) Photomicrographs: (b) Detail of central ridge structure; (c) Detail of spines on central ridge.

Diffuse coverage: composed of a uniform but sparse coverage of spines (Figs 2a, 7a), the following species can be included in this category:

Armitermes spininotus (Fig. 2): All surfaces are covered with spaced thin setae (Figs 2b, 2c).

Embiratermes heterotypus (Fig. 7): All surfaces are covered with a layer of aciculiform spines (Fig. 7b).

Broad coverage: characterized by a dense coverage of spines (Figs 4a, 21a, 23a, 24a), mainly aciculiform, and small spines in rows, with recurrent sclerotized spines, the following species can be included in this category:
Cahuallitermes intermedius: very similar to C. cumulans (see ahead).

Cornitermes cumulans (Fig. 4): The surface is covered by different types of spines, laterally to the large mesenteric tongue an elongated area of aciculiform spines (Fig. 4b), the distal region and the edge of the mesenteric tongues are covered with small spines in rows (Fig. 4c), the remain surfaces are covered with spaced robust spines.

Cornitermes silvestrii, Procornitermes araujoi, Procornitermes triacifer: very similar to $C$. cumulans (see above). 

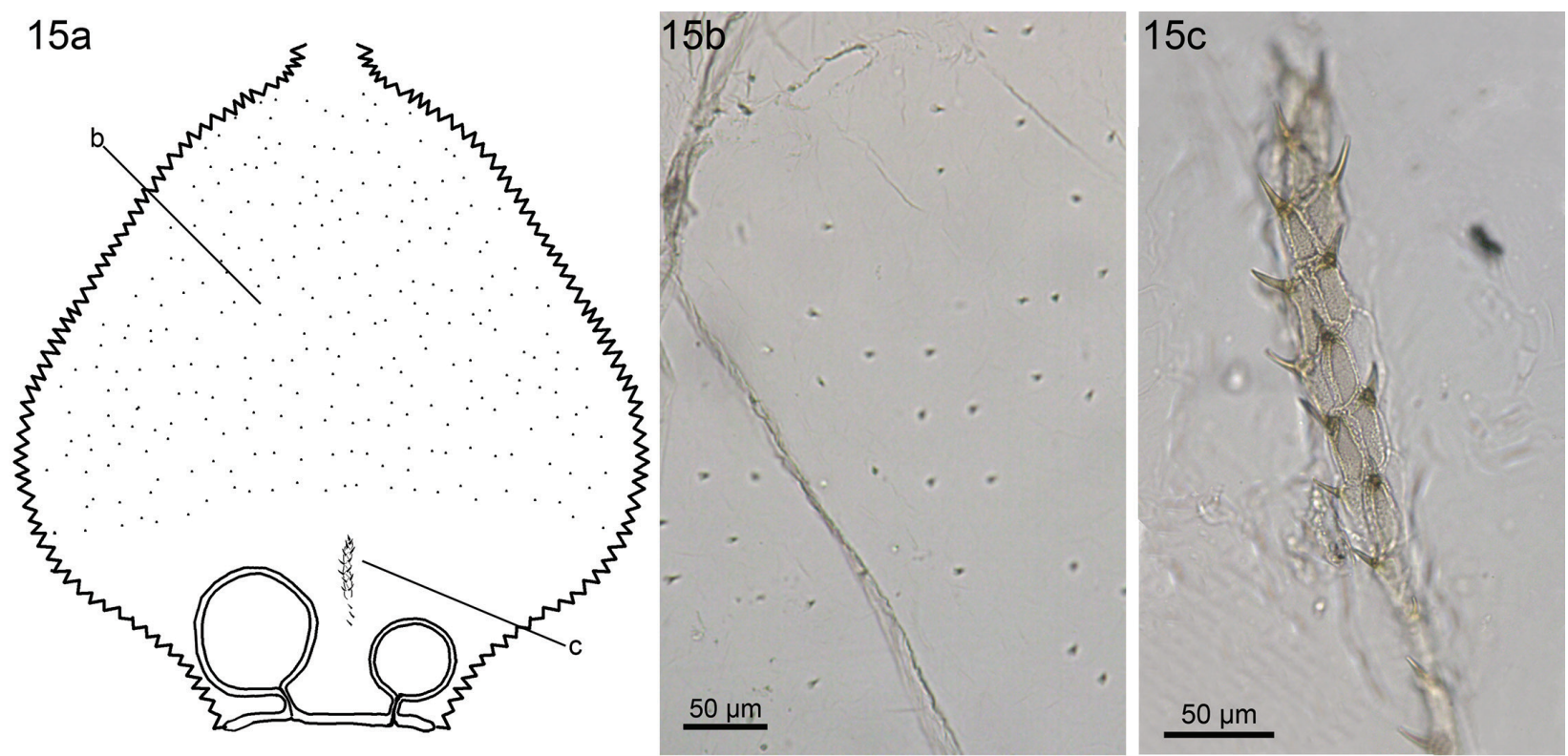

Figure 15. Labiotermes orthocephalus. (a) Schematic drawing of $\mathrm{P} 1$ showing arrangement of spines. (b, c) Photomicrographs: (b) Detail of the sparse short spines in the distal portion; (c) Detail of central ridge structure.
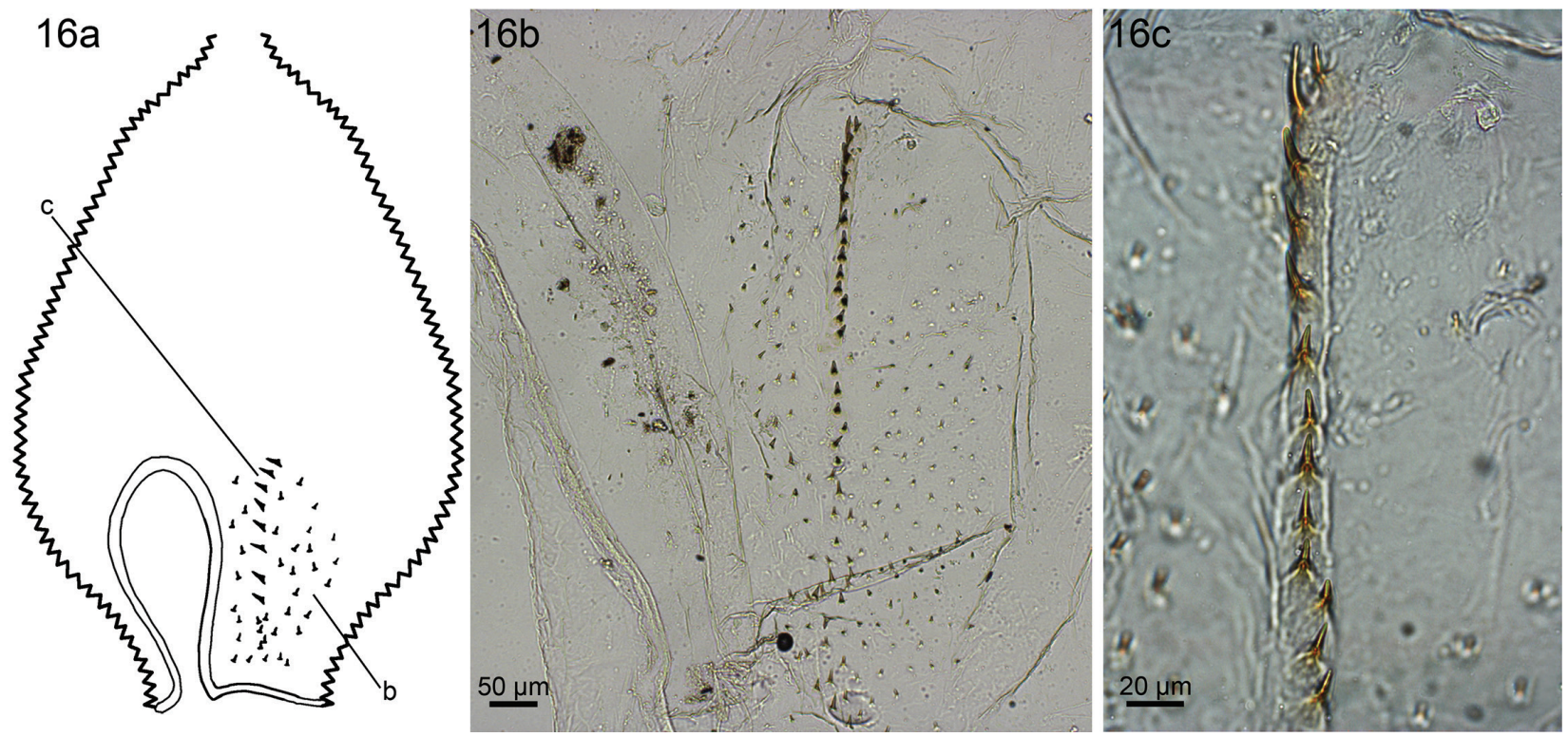

Figure 16. Mapinguaritermes peruanus. (a) Schematic drawing of $\mathrm{P} 1$ showing arrangement of spines. (b, c) Photomicrographs: (b) General view of the longitudinal row of stout spines, surround by robust spines; (c) Detail of stout spines.

Rhynchotermes nasutissimus: very similar to $R$. perarmatus (see ahead).

Rhynchotermes perarmatus (Fig. 21): laterally to the mesenteric tongue there is an elongated area covered with strongly sclerotized aciculiform spines (Fig. $21 b)$, the distal region is covered with small spines in rows (Fig. 21c).

Syntermes molestus (Fig. 23): similar to C. cumulans, the surface is covered by different types of spines, laterally to the large mesenteric tongue is an elongated area of strongly sclerotized aciculiform spines (Figs 23b, $23 \mathrm{~d}, 23 \mathrm{e})$, the distal region and the edge of the mes- enteric tongues are covered with small spines in rows (Figs 23c, 23f) and the remain surfaces are covered with spaced robust spines.

Syntermes spinosus (Fig. 24): laterally to the mesenteric tongue, an elongated area covered with robust spines (Fig. 24b), with a small area with strongly sclerotized aciculiform spines at the middle (Fig. 24c), the edges of the mesenteric tongues are covered with small spines in rows.

The species $A$. armiger, A. bidentatus and U. teevani (Fig. 25) does not fit clearly in the previous proposed 

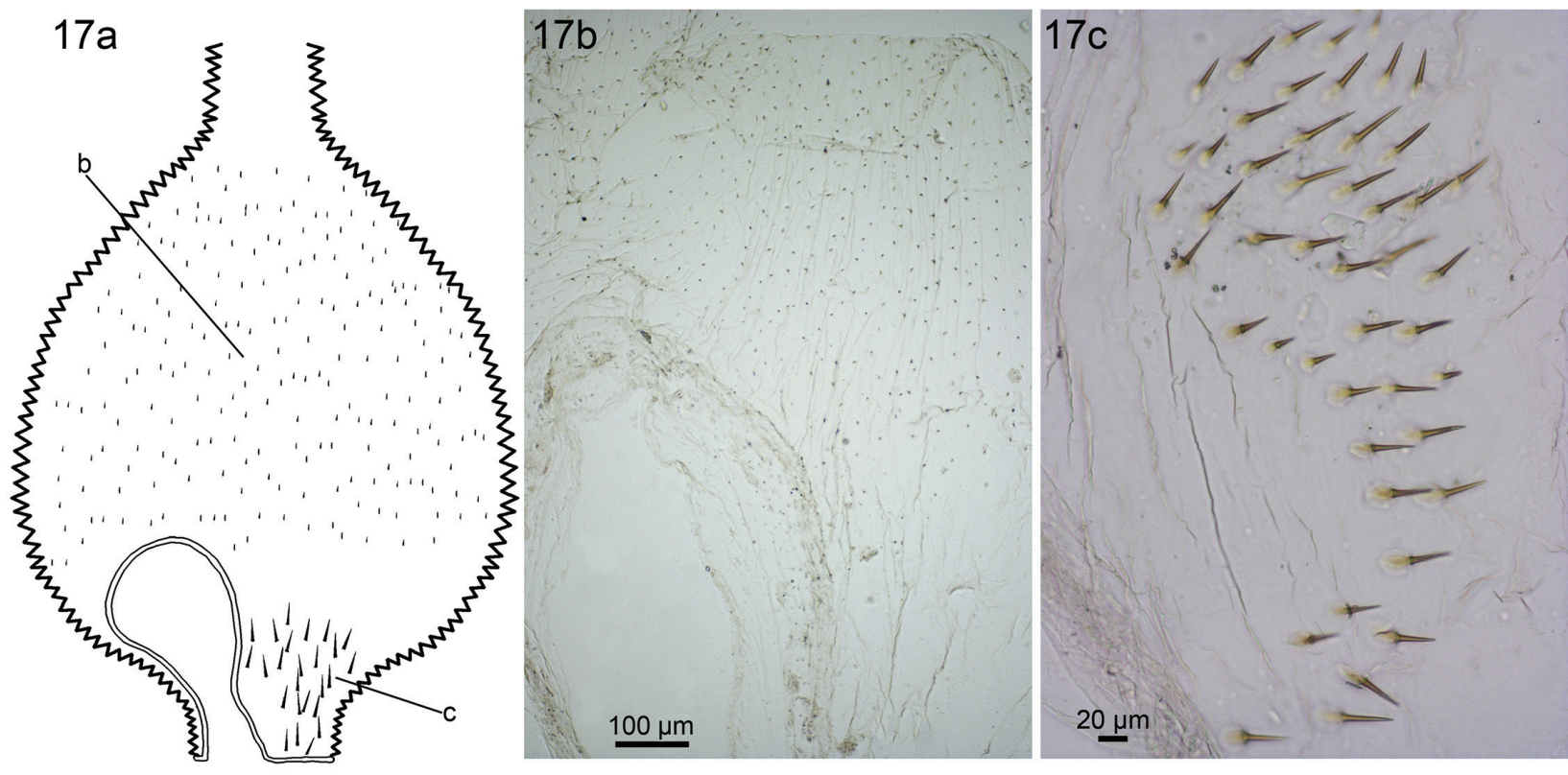

Figure 17. Macuxitermes triceratops. (a) Schematic drawing of P1 showing arrangement of spines. (b, c) Photomicrographs: (b) General view of the short spines in the distal region; (c) Set of aciculiform spines in detail.
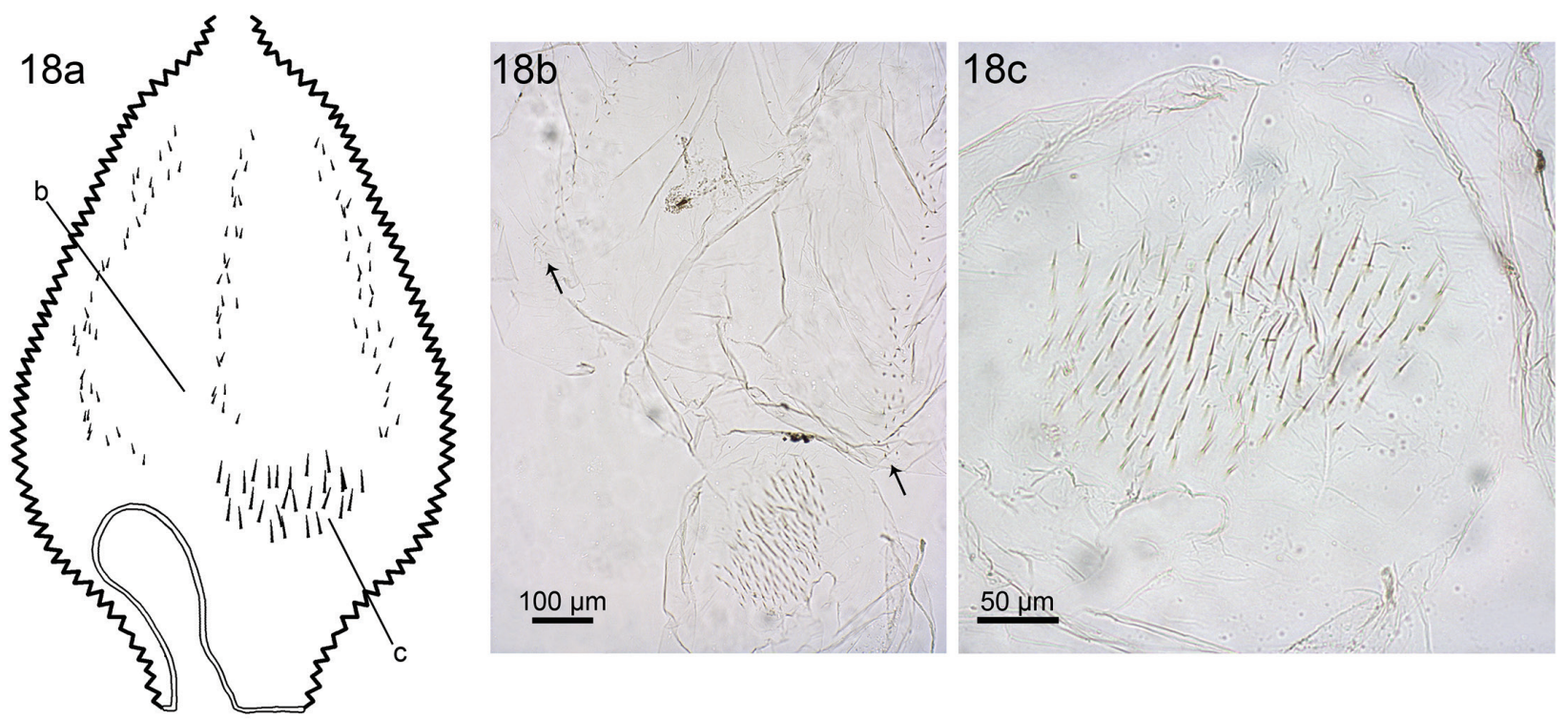

Figure 18. Noirotitermes noiroti. (a) Schematic drawing of P1 showing arrangement of spines. (b, c) Photomicrographs: (b) General view, arrows indicate the distal branches of spines; (c) Set of aciculiform spines in detail.

patterns, at the proximal region there is a irregular area covered with robust spines (Figs 25b, 25c), but without the longitudinal row of stout spines or the central ridge, and the distal region is covered with a single longitudinal and large row of spaced small spines, that can not be clearly recognize as equivalent to the broad coverage or the three branches of the proximal aciculiform pattern.

In a few of the species studied, the ornament coverage is reduced to short areas with small, sclerotized, aciculiform spines, i.e. in C. acignathus, C. bolivianus (Fig. 3) and P. lespesii (Fig. 19).

\section{Discussion}

\section{Taxonomic inferences}

Considering the four patterns of ornamentation, the Syntermitinae can be generally classified in four distinct groups: proximal aciculiform pattern (Acangaobitermes, Curvitermes, Cyrilliotermes, some Embiratermes species, Ibitermes tellustris, Noirotitermes, Silvestritermes); central ridge pattern (Embiratermes robustus, Ibitermes curupira, Mapinguaritermes and Labiotermes); diffuse coverage (Armitermes and Embiratermes heterotypus) 

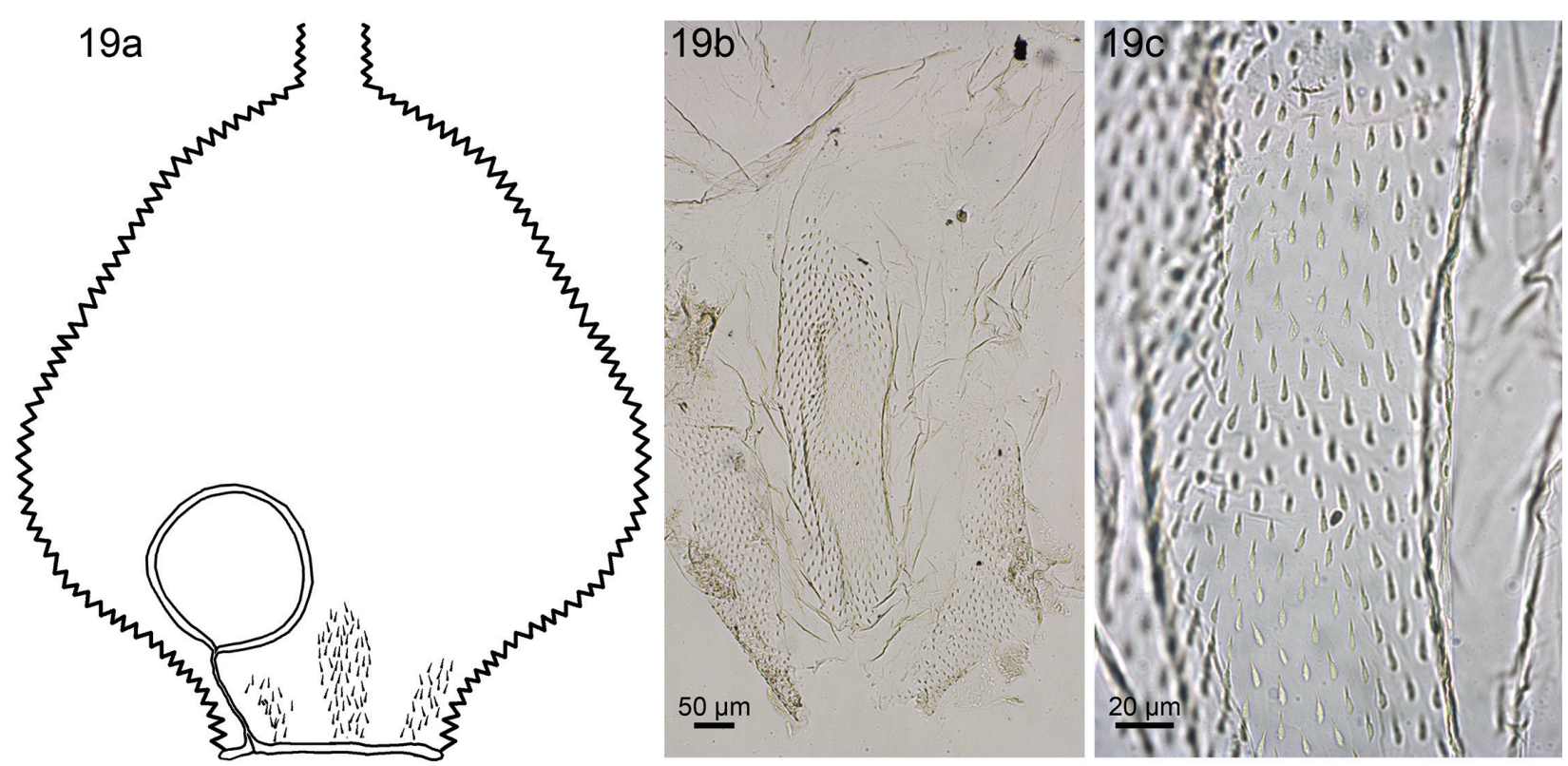

Figure 19. Procornitermes lespesii. (a) Schematic drawing of $\mathrm{P} 1$ showing arrangement of spines. (b, c) Photomicrographs: (b) General view showing three proximal sets of small spines; (c) Small spines with sclerotized base in detail.
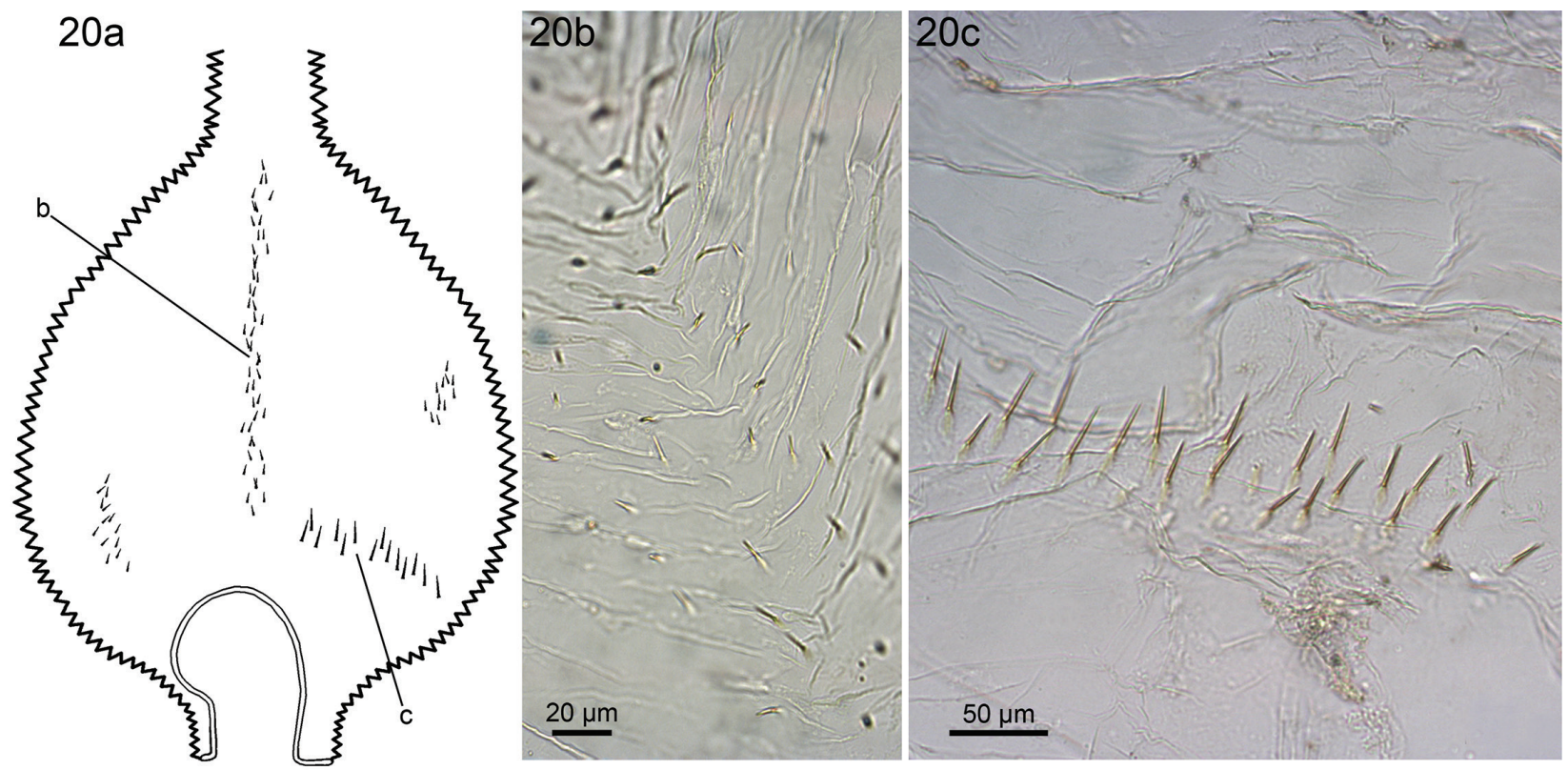

Figure 20. Paracurvitermes manni. (a) Schematic drawing of $\mathrm{P} 1$ showing arrangement of spines. (b, c) Photomicrographs: (b) Detail of the middle distal row of spines; (c) Transverse row of aciculiform spines in detail.

and broad coverage (Syntermes, Cornitermes, Rhynchotermes, Procornitermes araujoi and Procornitermes triacifer) (Table 2).

The ornamentation pattern in Syntermitinae is bilaterally symmetrical or asymmetrical (in a few species). The majority of genera of Syntermitinae have a consistent pattern of ornamentation among their species; the exceptions are Ibitermes, Embiratermes and Procornitermes, particularly Embiratermes. This indicates that these genera are not monophyletic, in agreement with observations of other gut anatomical characters (Cancello and Rocha 2013, for Procornitermes; personal observation for Embiratermes and Ibitermes, manuscript in preparation).

Although these structures may have potential phylogenetic information, their relevance as characters and the congruence with the gut anatomy need to be checked in most comprehensive studies. A preliminary phylogeny of Syntermitinae was proposed in Rocha et al. 2012, but the main objective in the study is just formulate a working hypothesis to test the monophyly of Armitermes, a more specific study is necessary to make phylogenetic inferences about the evolution of the ornaments. 


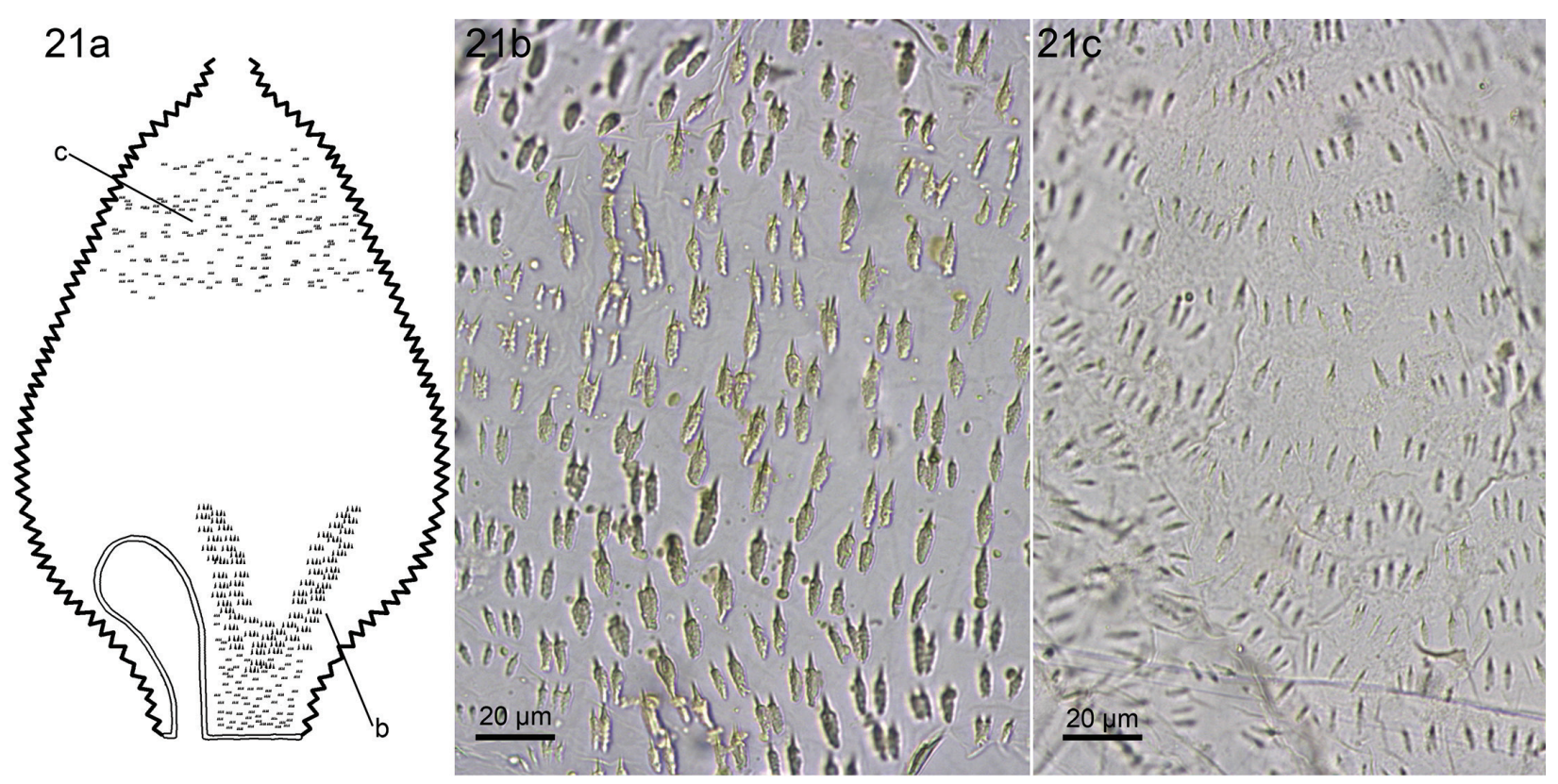

Figure 21. Rhynchotermes perarmatus. (a) Schematic drawing of P1 showing arrangement of spines. (b, c) Photomicrographs: (b) Detail of spines with strongly sclerotized base next to mesenteric tongue; (c) Detail of rows of small spines in the distal region.

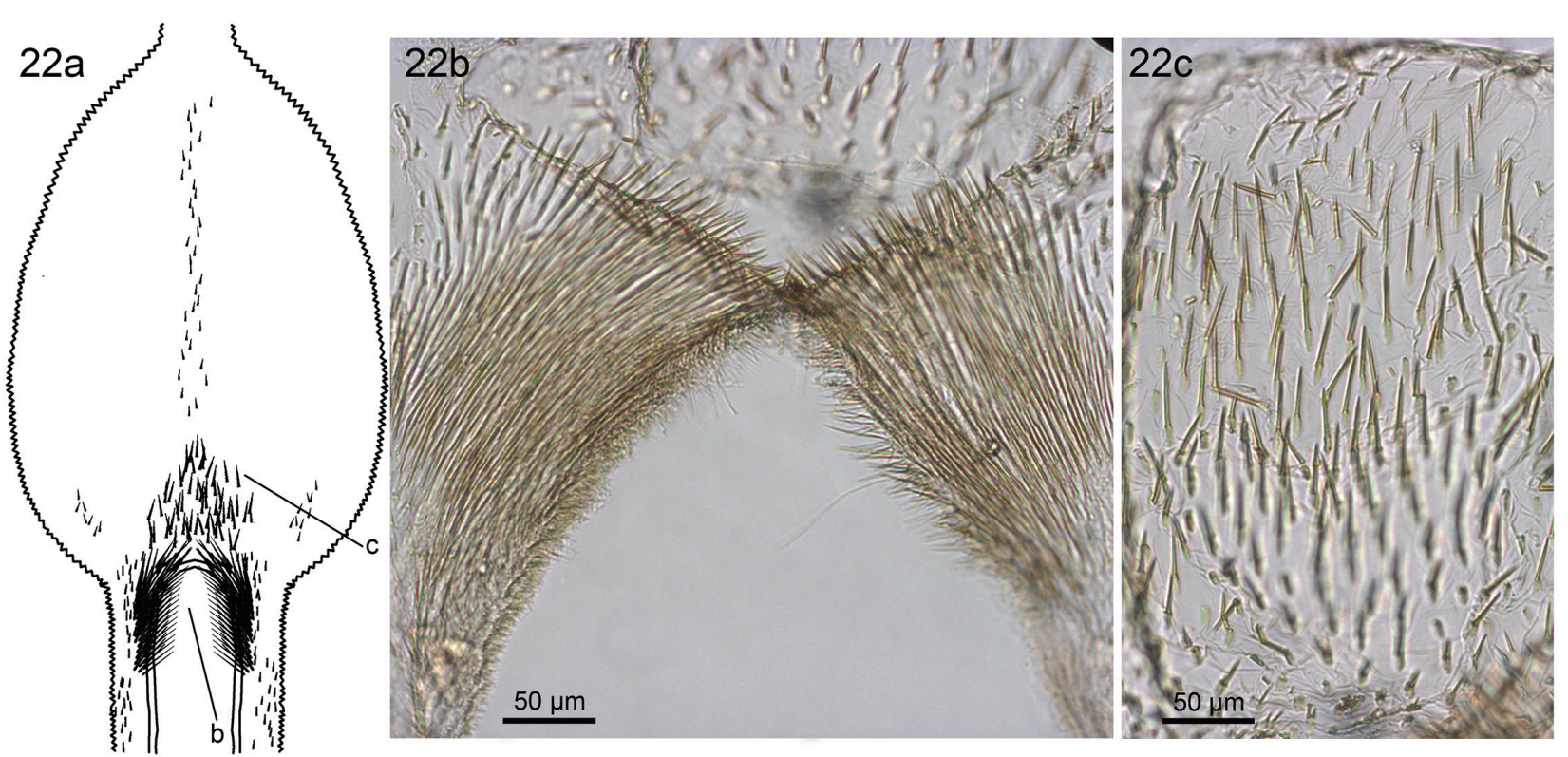

Figure 22. Silvestritermes euamignathus. (a) Schematic drawing of $\mathrm{P} 1$ showing arrangement of spines. (b, c) Photomicrographs: (b) Palisade of thin aciculiform spines around the mesenteric tongue; (c) Detail of aciculiform spines just after the mesenteric tongue.

\section{Feeding habit inferences}

In studies of termite faunas, the species are commonly classified by diet. The categories are defined by a humification gradient, which ranges from whole plant matter (such as wood and dead leaves) to decomposed cellulosic compounds dispersed in the soil (see Donovan et al. 2001 for a more detailed description). Although the classification by feeding groups is widely used, more recent studies have indicated that there is a continuum among termite feeding preferences (Bourguignon et al. 2010).
No specific proposal has been made for a classification of the feeding habits of all Syntermitinae species. Based on field notes accompanying specimens deposited in the MZUSP, and inferences from worker mandibles and gut morphology, we made a compilation and a classification for their diet, and compared feeding habits and P1 patterns of ornamentation among the species examined (Table 2).

The pattern of ornamentation in Syntermitinae appears to be generally related to the feeding habit, and reflects the humification gradient. Species that feed lower 

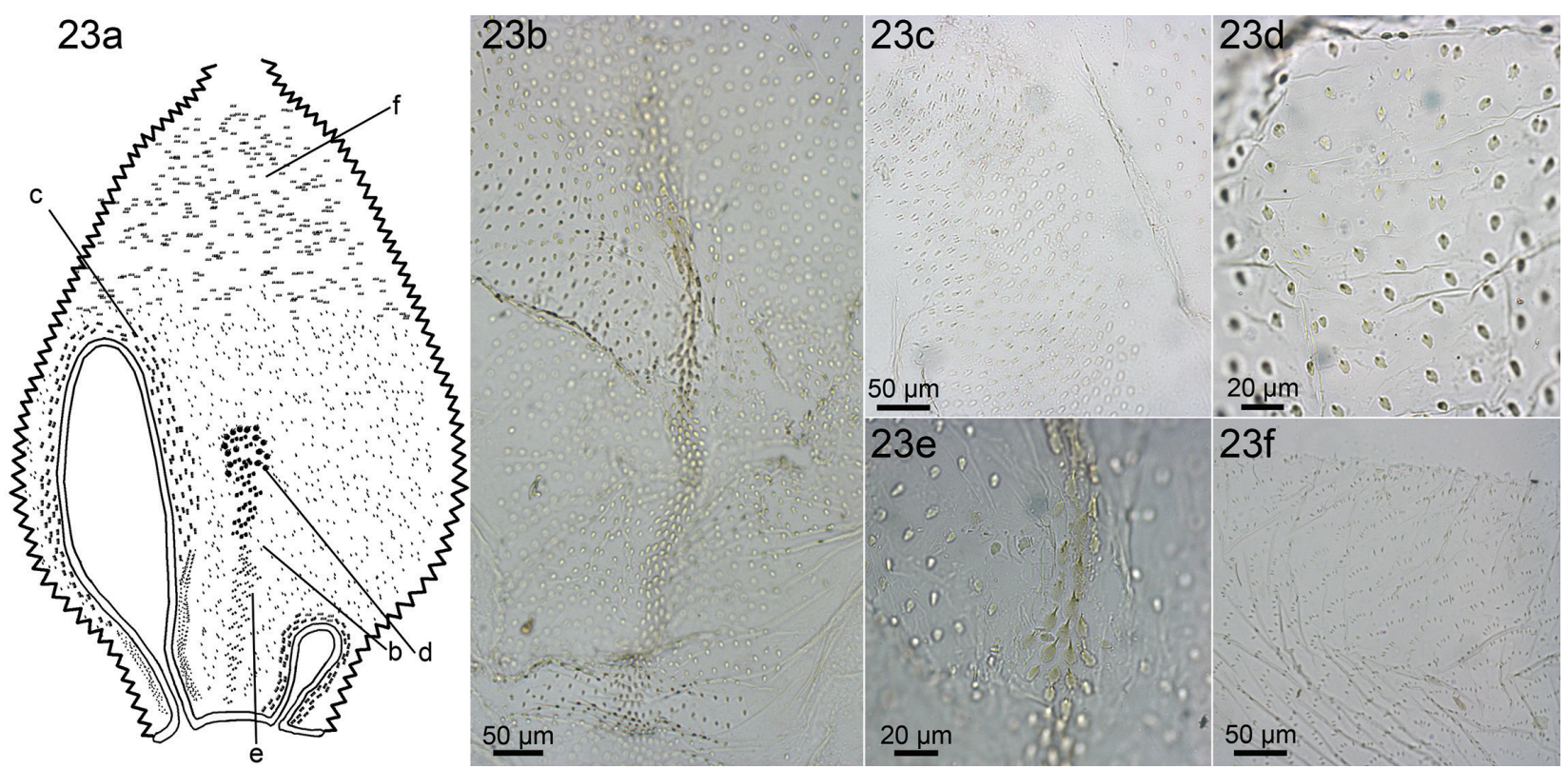

Figure 23. Syntermes molestus. (a) Schematic drawing of $\mathrm{P} 1$ showing arrangement of spines. (b-f) Photomicrographs: (b) General view of the region between the mesenteric tongues; (c) Detail of small spines in rows adjacent to the mesenteric tongue; (d) Detail of spines with strongly sclerotized base between the mesenteric tongues; (e) Detail of strongly sclerotized spines in the middle of the region between the mesenteric tongues; (f) Detail of the small spines in rows in the distal region.
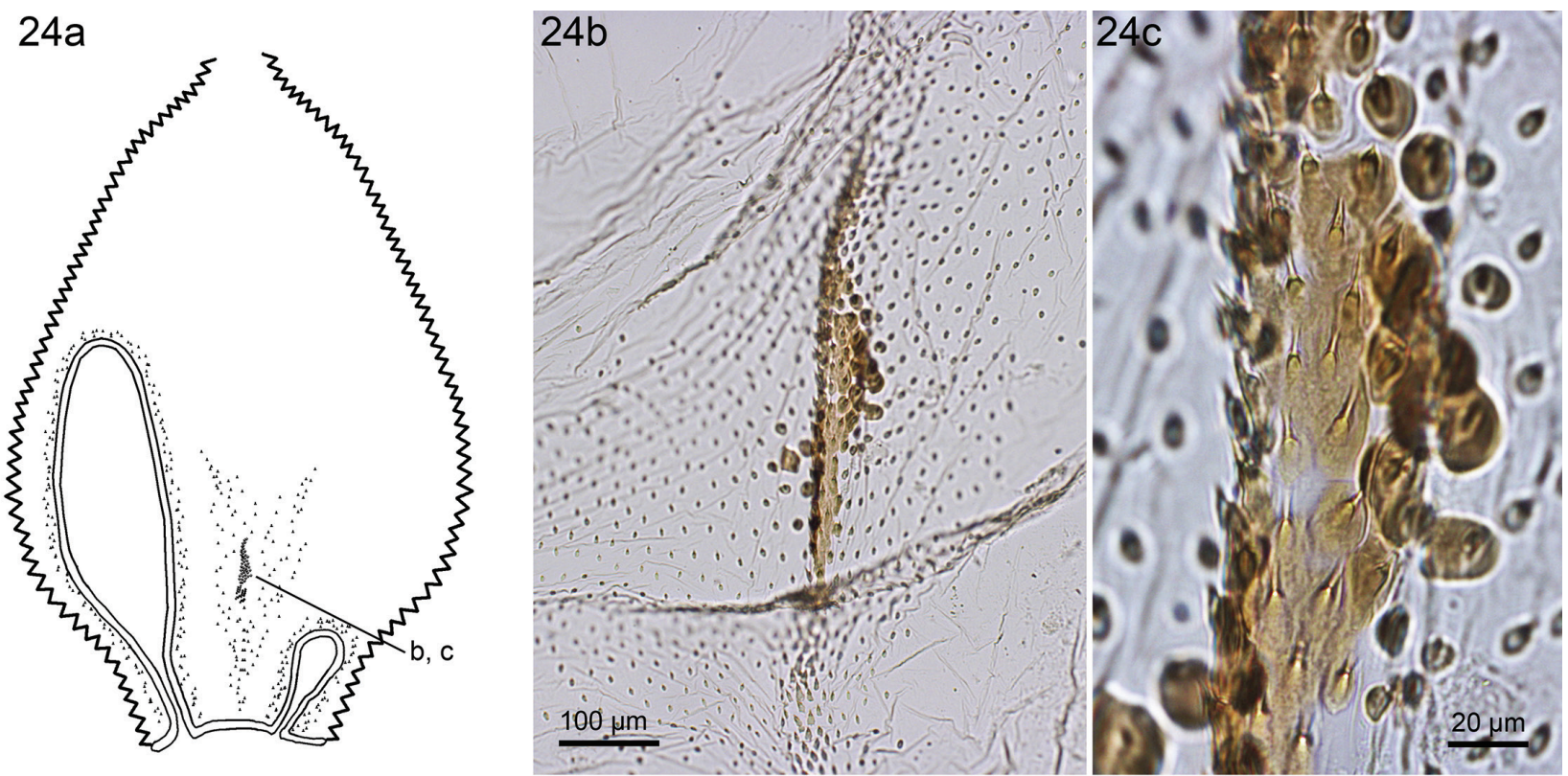

Figure 24. Syntermes spinosus. (a) Schematic drawing of P1 showing arrangement of spines. (b, c) Photomicrographs: (b) General view of sclerotized spines between the mesenteric tongues; (c) Detail of the strongly sclerotized spines with their bases merged.

in the humification gradient (litter-feeders, grass-feeders and wood-feeders) mainly display a mosaic pattern, with a wide and heterogeneous coverage of small spines (for example Syntermes, Cornitermes, Rhynchotermes). Species that feed on humidified resources (intermediateand soil-feeders) have a more centralized pattern, with structures concentrated only in the proximal region of P1 (for example Silvestritermes, Curvitermes, Mapin- guaritermes, Labiotermes) (see Table 2). This inference may be useful as an additional character to determine the species' diet, combined with other characteristics of the gut. However, some of the species examined in this study are exceptions; for instance, $P$. lespesii and $C$. bolivianus are known as, respectively, wood-feeder and litter-feeder species, although their P1 ornamentation is much reduced. 


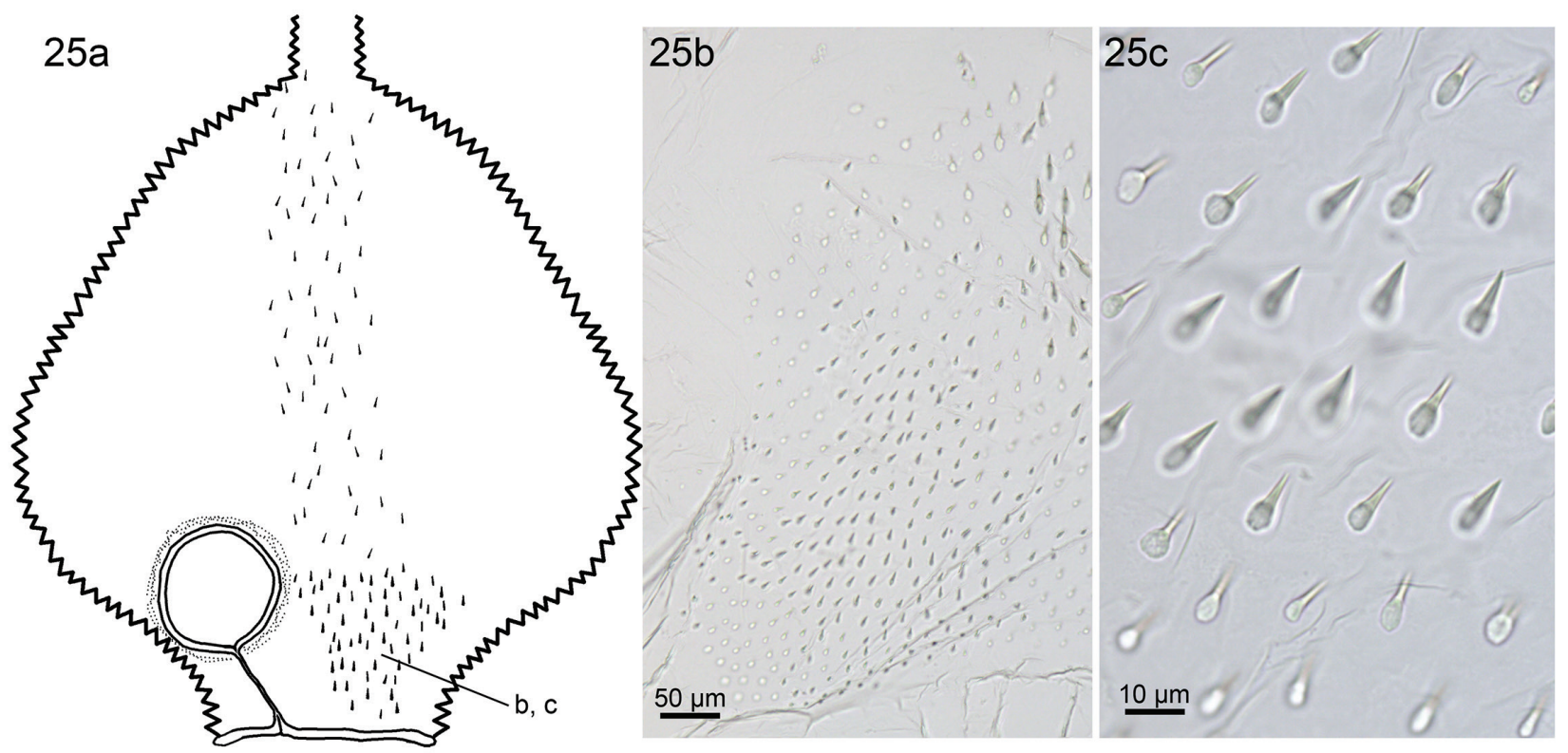

Figure 25. Uncitermes teevani. (a) Schematic drawing of P1 showing arrangement of spines. (b, c) Photomicrographs: (b) General view of the robust spines covering the proximal portion; (c) Detail of robust spines.

Table 2. Association between patterns of ornaments for the species studied, and their feeding habits.

\begin{tabular}{|c|c|c|}
\hline Species & Pattern of ornaments & Feeding habit \\
\hline Acangaobitermes krishnai & Proximal aciculiform & Soil-feeder \\
\hline Curvitermes odontognathus & Proximal aciculiform & Soil-feeder \\
\hline Cyrilliotermes angulariceps & Proximal aciculiform & Soil-feeder \\
\hline Embiratermes brevinasus & Proximal aciculiform & Intermediate \\
\hline Embiratermes festivellus & Proximal aciculiform & Intermediate \\
\hline Embiratermes ignotus & Proximal aciculiform & Intermediate \\
\hline Embiratermes silvestrii & Proximal aciculiform & Intermediate \\
\hline Ibitermes tellustris & Proximal aciculiform & Intermediate \\
\hline Noirotitermes noiroti & Proximal aciculiform & Intermediate \\
\hline Macuxitermes triceratops & Proximal aciculiform & Intermediate \\
\hline Paracurvitermes manni & Proximal aciculiform & Soil-feeder \\
\hline Silvestritermes euamignathus & Proximal aciculiform & Intermediate \\
\hline Armitermes armiger & Unclear & Intermediate \\
\hline Armitermes bidentatus & Unclear & Intermediate \\
\hline Armitermes spininotus & Diffuse coverage & Intermediate \\
\hline Uncitermes teevani & Unclear & Intermediate \\
\hline Embiratermes heterotypus & Diffuse coverage & Intermediate \\
\hline Embiratermes robustus & Central ridge & Intermediate \\
\hline Ibitermes curupira & Central ridge & Intermediate \\
\hline Labiotermes emersoni & Central ridge & Intermediate \\
\hline Labiotermes labralis & Central ridge & Intermediate \\
\hline Labiotermes leptothrix & Central ridge & Intermediate \\
\hline Labiotermes orthocephalus & Central ridge & Intermediate \\
\hline Mapinguaritermes peruanus & Central ridge & Intermediate \\
\hline Cahuallitermes intermedius & Broad coverage & Litter-feeder \\
\hline Cornitermes acignathus & Reduced coverage & Litter-feeder \\
\hline Cornitermes cumulans & Broad coverage & $\begin{array}{l}\text { Litter-feeder/ } \\
\text { Grass-feeder }\end{array}$ \\
\hline Cornitermes bolivianus & Reduced coverage & Litter-feeder \\
\hline Cornitermes silvestrii & Broad coverage & Litter-feeder \\
\hline Procornitermes araujoi & Broad coverage & $\begin{array}{l}\text { Wood-feeder/ } \\
\text { Litter-feeder }\end{array}$ \\
\hline Procornitermes lespesii & Reduced coverage & Wood-feeder \\
\hline
\end{tabular}

\begin{tabular}{c|c|c}
\hline Species & Pattern of ornaments & Feeding habit \\
\hline Procornitermes triacifer & Broad coverage & $\begin{array}{l}\text { Wood-feeder/ } \\
\text { Litter-feeder }\end{array}$ \\
\hline Rhynchotermes nasutissimus & Broad coverage & $\begin{array}{l}\text { Litter-feeder/ } \\
\text { Grass-feeder }\end{array}$ \\
\hline Rhynchotermes perarmatus & Broad coverage & $\begin{array}{l}\text { Litter-feeder/ } \\
\text { Grass-feeder }\end{array}$ \\
\hline Syntermes molestus & Broad coverage & Grass-feeder \\
\hline Syntermes spinosus & Broad coverage & Grass-feeder \\
\hline
\end{tabular}

\section{Function in termite digestion}

As the P1 ornaments have never been described in detail for Termitidae species, we can only speculate as to their function. Investigating their specific function is outside the scope of this paper, but we can make some suggestions based on morphological inference and analogies with the functions of P2 suggested by Donovan et al. (2000).

These structures may function as an abrasive surface for the food mass that enters from the midgut. This hypothesis is supported by the location of the ornaments, only in the proximal part of the convex side of the mesenteric arch (see Fig. 1). However, in some cases the ridges may be irrelevant for this function, for example the isolated central ridges in Labiotermes (Figs 12-15) measure around $50-100 \mu \mathrm{m}$ and the P1 diameter varies between 1-2 $\mathrm{mm}$, and it is difficult to explain how a single structure of this size can act on the food mass.

Another possible explanation is microbial inoculation. This hypothesis is supported by the usual presence of what appears to be a bacterial film covering the spines, and some points regarding this possibility need to be considered. The $\mathrm{pH}$ and oxygenation conditions inside the first proctodeal segment may be very differ- 
ent from the third proctodeal segment, which implies that the bacterial flora will also necessarily be different. Bignell and Eggleton (1995) studied the $\mathrm{pH}$ conditions inside each segment of the digestive tract in various termite species, and found that P1 may be more alkaline than P3. Schmitt-Wagner et al. (2003) demonstrated for two Cubitermes species (African soil-feeder termites) that inside each hindgut compartment (P1-P5) the symbiont assemblage is composed of distinct types and proportions of microbial groups; this reinforces a microbial-inoculation hypothesis. The mean size of the ornamentation is approximately $20 \mu \mathrm{m}$, suggesting an association of the bacteria of the micro-oxic region, the peripheral region of the lumen, of approximately $100 \mu \mathrm{m}$, with oxygen availability (Brune and Friedrich 2000). To confirm this, more-detailed studies are needed to bolster this hypothesis.

In other groups of Termitidae, with the same range of feeding habits, ornamentation appears to be absent. For example, in Nasutitermitinae the species have a variety of feeding habits that cover the entire humification gradient, but we never find ornaments in their first proctodeal segment (personal observation). This suggests that in the course of termite evolution, many different strategies have emerged in response to the problems of digesting similar types of food.

\section{Conclusion}

Additional information is needed in order to determine the functions and importance of these structures in termite digestion, although the variability among the species clearly shows the taxonomic value of the structure. This character may have taxonomic value in other termite groups, especially for Termitinae and Apicotermitinae, although further studies are needed to confirm this possibility.

\section{Acknowledgments}

The first author thanks the FAPESP (Fundação de Amparo à Pesquisa do Estado de São Paulo; Proc. no. 2012/009529) for financial support, and CNPq (Conselho Nacional de Desenvolvimento Científico e Tecnológico; Proc. no. 304765/2007-4). We are grateful to Dr. Eliana Marques Cancello (MZUSP), Dr. Adriana Carolina Cuezzo (MZUSP) and Dr. Benjamin Wipfler (Friedrich-Schiller-University of Jena) for their constructive reviews and opinions, and to Dr. Cleide Costa (MZUSP) for allowing us to use the optical equipment at the MZUSP for image capture.

\section{References}

Bignell DE, Eggleton P (1995) On the elevated intestinal pH of higher termites (Isoptera: Termitidae). Insectes Sociaux 42: 57-69. doi: 10.1007/BF01245699

Bourguignon T, Sobotník J, Lepoint G, Martin J, Hardy OJ, Dejean A, Roisin Y (2010) Feeding ecology and phylogenetic structure of a complex neotropical termite assemblage, revealed by nitrogen stable isotope ratios. Ecological Entomology 36: 261-269. doi: 10.1111/j.1365-2311.2011.01265.x

Brune A (2014) Symbiotic digestion of lignocellulose in termite guts. Nature Reviews Microbiology 12(3): 168-180. doi: 10.1038/nrmicro3182

Brune A, Friedrich M (2000) Microecology of the termite gut: structure and function on a microscale. Current Opinion in Microbiology 3: 263-269. doi: 10.1016/S1369-5274(00)00087-4

Cancello EM, Rocha MM (2013) Comparative morphology of the digestive tube in species of Procornitermes Emerson (Isoptera, Termitidae, Syntermitinae). Deutsche Entomologische Zeitschrift 60 : 147-153. doi: 10.1002/mmnd.201300020

Donovan SE, Jones DT, Sands WA, Eggleton P (2000) Morphological phylogenetics of termites (Isoptera). Biological Journal of the Linnean Society 70(3): 467-513. doi: 10.1111/j.1095-8312.2000. tb01235.X

Donovan SE, Eggleton P, Bignell DE (2001) Gut content analysis and a new feeding group classification of termites. Ecological Entomology 26: 356-366. doi: 10.1046/j.1365-2311.2001.00342.x

Grassé PP (1982) Termitologia: Anatomie, physiologie, biologie, systématique des termites. Tôme I, Anatomie, physiologie, reproduction. Masson, Paris, 715 pp.

Krishna K, Grimaldi DA, Krishna V, Engel MS (2013) Treatise on the Isoptera of the world 1. Introduction. Bulletin of the American Museum of Natural History 377: 1-196. doi: 10.1206/377.7

Kovoor J (1969) Anatomie comparée du tube digestif des termites. II. Sous-famille des Nasutitermitinae. Insectes Sociaux 16: 195-234. doi: 10.1007/BF02223410

Noirot C (1995) The gut of Termites (Isoptera). Comparative anatomy, systematics, phylogeny. I. Lower Termites. Annales de la Société Entomologique de France 31: 197-226.

Noirot C (2001) The gut of Termites (Isoptera). Comparative anatomy, systematics, phylogeny. II. Higher Termites (Termitidae). Annales de la Société Entomologique de France 37: 431-471.

Rocha MM, Cancello EM, Carrijo TF (2012) Neotropical termites: revision of Armitermes Wasmann (Isoptera, Termitidae, Syntermitinae) and phylogeny of the Syntermitinae. Systematic Entomology 37: 793-827. doi: 10.1111/j.1365-3113.2012.00645.x

Sands WA (1972) The soldierless termites of Africa (Isoptera, Termitidae). Bulletin of the British Museum (Natural History) 18: 1-244.

Schmitt-Wagner D, Friedrich MW, Wagner B, Brune A (2003) Phylogenetic diversity, abundance, and axial distribution of bacteria in the intestinal tract of two soil-feeding termites (Cubitermes spp.). Applied and Environmental Microbiology 69: 6007-6017. doi: 10.1128/AEM.69.10.6007-6017.2003 